\title{
Calcium Currents and Graded Synaptic Transmission between Heart Interneurons of the Leech
}

\author{
James D. Angstadt and Ronald L. Calabrese \\ Department of Biology, Emory University, Atlanta, Georgia 30322
}

\begin{abstract}
Synaptic transmission between reciprocally inhibitory heart interneurons (HN cells) of the medicinal leech was examined in the absence of Na-mediated action potentials. Under voltage clamp, depolarizing steps from a holding potential of $-60 \mathrm{mV}$ elicited 2 kinetically distinct components of inward current in the presynaptic HN cell: an early transient current that inactivates within $200 \mathrm{msec}$ and a persistent current that only partially decays over several seconds. Both currents begin to activate near $-60 \mathrm{mV}$. Steady-state inactivation occurs over the voltage range between -70 and -45 $\mathrm{mV}$ and is completely removed by 1-2-sec hyperpolarizing voltage steps to $-80 \mathrm{mV}$. The inward currents are carried by $\mathrm{Ca}^{2+}, \mathrm{Ba}^{2+}$, or $\mathrm{Sr}^{2+}$ ions, but not by $\mathrm{Co}^{2+}, \mathrm{Mn}^{2+}$, or $\mathrm{Ni}^{2+}$. These same inward currents underlie the burst-generating plateau potentials previously described in HN cells (Arbas and Calabrese, 1987a,b). With a presynaptic holding potential of $-60 \mathrm{mV}$, the threshold for transmitter release is near $-45 \mathrm{mV}$. Postsynaptic currents in the contralateral HN cell have a reversal potential near $-60 \mathrm{mV}$. The largest postsynaptic currents (300-400 pA) exhibit an initial peak response that is followed by a more slowly decaying component. The persistent component of $\mathrm{Ca}^{2+}$ current in the presynaptic neuron is strongly correlated with the prolonged component of the postsynaptic current, while the transient presynaptic $\mathrm{Ca}^{2+}$ current appears to correspond to the early peak of postsynaptic current. These data are consistent with the hypothesis that voltage-dependent calcium currents contribute to the oscillatory capability of reciprocally inhibitory HN cells by (1) generating the plateau potential that drives the burst of action potentials and (2) underlying the release of inhibitory transmitter onto the contralateral cell.
\end{abstract}

Blood is propelled through the circulatory system of the leech by rhythmic contractions of 2 lateral heart tubes. The timing and coordination of these contractions are controlled by a central neural oscillator comprised of bilateral pairs of rhythmically active heart interneurons ( $\mathrm{HN}$ cells) found in the first 7 segmental ganglia (Gl-G7; Thompson and Stent, 1976a; Calabrese, 1977; Peterson and Calabrese, 1982). The rhythmic activity has a cycle period of approximately $10 \mathrm{sec}$ and consists

\footnotetext{
Received May 14, 1990; revised Sept. 26, 1990; accepted Oct. 19, 1990.

We wish to thank Dr. Ted Simon for providing computer programs useful in the analysis of the data and Dr. Donald H. Edwards for generously supplying us with equipment used in some of the experiments. We also thank Dr. Wolfgang $O$. Friesen for his comments on the manuscript. This work was supported by NIH Grant NS24072 to R.L.C. and NRSA Fellowship NS08089 to J.D.A.

Correspondence should be addressed to James D. Angstadt, Department of Biology, Gilmer Hall, University of Virginia, Charlottesville, VA 22901.

Copyright (C) 1991 Society for Neuroscience 0270-6474/91/110746-14\$03.00/0
}

of bursts of action potentials separated by bouts of inhibitory input, in which the membrane potential becomes hyperpolarized to near $-60 \mathrm{mV}$ (Fig. $1 B$ ). The synaptic connections between the most rostral 4 pairs of $\mathrm{HN}$ cells, which control the beat timing of heart tube contractions, are illustrated in Figure $1 A$. In $\mathrm{G} 3$ and $\mathrm{G} 4$, each pair of $\mathrm{HN}$ cells make direct reciprocal inhibitory synaptic connections across the ganglion. The $\mathrm{HN}(1)$ and $\mathrm{HN}(2)$ cell pairs are not reciprocally inhibitory; their axons serve as coordinating fibers to ensure that ipsilateral $\mathrm{HN}(3)$ and HN(4) cells fire in phase. Rhythmic antiphasic bursting of contralateral IIN(3) and IIN(4) cells continues following transection of connective nerves between ganglia, though the 2 oscillations are no longer phase locked (Peterson, 1983). Thus, each reciprocally inhibitory pair of $\mathrm{HN}(3)$ and $\mathrm{HN}(4)$ cells is a competent oscillator (Peterson, 1983; Calabrese et al., 1989).

The critical timing transition in the oscillation of $\mathrm{HN}$ cell pairs occurs when the currently inactive $\mathrm{HN}$ cell escapes from inhibition, generates a burst, and inhibits its previously active contralateral partner (Peterson, 1983). There are several mechanisms that could explain this recovery. For example, HN cells could possess voltage-gated conductances that cause them to depolarize and form a burst in response to inhibition. We have recently characterized a hyperpolarization-activated inward current, $I_{h}$, that causes depolarization in response to inhibitory inputs. Suppression of $I_{h}$ with extracellular $\mathrm{Cs}^{+}$severely disrupts the normal bursting activity of $\mathrm{HN}$ cell pairs in G3 or G4 (Angstadt and Calabrese, 1989). The burst itself is driven by a voltage- and $\mathrm{Ca}^{2+}$-dependent plateau potential (Arbas and Calabrese, 1987a). The plateau depolarization underlies the burst of impulses; these impulses propagate to more posterior ganglia, where they generate barrages of IPSPs in other HN cells or heart motor neurons (HE cells). Plateau potentials also elicit transmitter release independent of action potential generation and will support uscillation between bilateral pairs of reciprocally inhibitory HN cells in G3 or G4 (Arbas and Calabrese, 1987b). Another mechanism for recovery to burst threshold could be a progressive decrease in the strength of inhibitory inputs during the burst of the contralateral HN cell. Previous studies of synaptic transmission between $\mathrm{HN}$ cells provide evidence for both spike-mediated and tonic (graded) components of transmitter release (Nicholls and Wallace, 1978a,b; Arbas and Calabrese, 1987a,b). However, no evidence for facilitation or depression of spike-mediated synaptic transmission was found (Nicholls and Wallace, 1978a,b; Peterson, 1983). On the other hand, the time dependence of graded synaptic transmission was not examined.

In this study, we used the discontinuous current-clamp (DCC) and single-electrode voltage-clamp (SEVC) techniques to examine $\mathrm{Ca}^{2+}$ currents and graded synaptic transmission between 
reciprocally inhibitory $\mathrm{HN}$ cells. Our data show that plateau potentials are driven by at least 2 kinetically distinct $\mathrm{Ca}^{2+}$ currents. These same currents appear to underlie graded synaptic transmission between reciprocally inhibitory $\mathrm{HN}$ cells in G3 and G4. The synaptic transfer function is shown to occur over the same voltage range traversed by $\mathrm{HN}$ cells during bursting activity in normal physiological saline. Finally, postsynaptic currents were observed to decay significantly during presynaptic voltage steps with durations comparable to a typical $\mathrm{HN}$ cell burst $(5 \mathrm{sec})$. These results are consistent with the hypothesis that 3 factors may contribute to the generation of oscillatory activity by reciprocally inhibitory HN cells: (1) activation of calcium currents that underlie a burst-generating plateau potential, (2) synaptic inhibition of the contralateral $\mathrm{HN}$ cell during the burst-time-dependent decay of the tonic component of this inhibitory drive could contribute to the rate of recovery of the inactive HN cell toward burst threshold, and (3) activation of $I_{h}$, which leads to burst generation by active depolarization of the inhibited HN cell.

\section{Materials and Methods}

Leeches (Hirudo medicinalis) were obtained from European suppliers and stored at $15^{\circ} \mathrm{C}$. After anesthetizing the leech in cold saline, individual ganglia were isolated by dissection and pinned in small Petri dishes. Ganglia were continuously superfused with normal leech saline (Nicholls and Baylor, 1968) containing (in mм) $\mathrm{NaCl}, 115 ; \mathrm{KCl}, 4$; $\mathrm{CaCl}_{2}, 1.8$; glucose, 10; and HEPES buffer, 10, adjusted to $\mathrm{pH} 7.4$. HN cells were identified by the posterolateral position of their somata on the ventral surface of the ganglion and their characteristic bursting pattern. Once HN cells were identified in normal saline, ganglia were superfused with $\mathrm{Na}$-free saline ( $\mathrm{Na}^{+}$replaced with an equimolar concentration of $N$-mcthyl-D-glucamine). No change in cellular properties, other than loss of action potentials and a hyperpolarization by approximately $10 \mathrm{mV}$, was observed in $\mathrm{Na}$-free saline over the time course of our experiments $(10-15 \mathrm{~min})$. CsCl $(4 \mathrm{mM})$ was added to block $I_{h}$, and $5 \mathrm{~mm}$ 4-aminopyridine (4-AP) was added to suppress an $I_{A}$-like outward current. In many experiments, $\left[\mathrm{Ca}^{2+}\right.$, was raised to $5 \mathrm{mM}$ to increase the amplitude of $\mathrm{Ca}^{2+}$ currents and of synaptic responses. In these modified salines, the physiological osmotic strength was maintained by reductions in the concentration of $N$-methyl-D-glucamine. In some salines, $\mathrm{Ca}^{2+}$ was replaced with an equimolar concentration of $\mathrm{Ba}^{2+}, \mathrm{Sr}^{2+}, \mathrm{Co}^{2+}$, $\mathrm{Mn}^{2+}$, or $\mathrm{Ni}^{2+}$. Ethylene glycol bis( $\beta$-aminoethyl)ether- $N, N^{\prime}$-tetra-acetic acid (EGTA; $2 \mathrm{mM}$ ) was sometimes added to $\mathrm{Co}^{2+}$-substituted saline to further reduce $\left[\mathrm{Ca}^{2+}\right]_{0}$. Modified salines were made in small quantities every few days, and $\mathrm{pH}$ was checked regularly.

HN cclls occur as bilatcral pairs in segmental ganglia 1-7 and are indexed according to ganglion and side [e.g., $\mathrm{HN}(\mathrm{R}, 1) \ldots \mathrm{HN}(\mathrm{L}, 7)]$. Experiments on graded synaptic transmission were carried out in isolated $\mathrm{G} 3$ or $\mathrm{G} 4$, where the bilateral HN cells are connected by reciprocal inhibitory synapses (Thompson and Stent, 1976b; Tolbert and Calabrese, 1985).

HN cells were penetrated with thin-walled $(1 \mathrm{~mm}$ outer diameter, $0.75 \mathrm{~mm}$ inner diameter) borosilicate microelectrodes filled with $2 \mathrm{M}$ $\mathrm{K}$-acetate and $1.5 \mathrm{~m}$ tetraethylammonium (TEA) acetate (which suppresses both the $I_{A}$-like current and a delayed-rectifier-like outward current). Microelectrodes had resistances of 60-70 $\mathrm{M} \Omega$ and time constants of $0.2-0.5 \mathrm{msec}$. By comparison, the membrane time constant of the HN cell in Na-free saline is approximately $70 \mathrm{msec}$ (T. W. Simon and $R$. L. Calabrese, unpublished observations). The membrane potential of each $\mathrm{HN}$ ccll was controlled with a separate Axoclamp- $2 \Lambda \mathrm{mi}-$ croelectrode voltage clamp (Axon Instruments) used in either discontinuous current-clamp (DCC) or single-electrode voltage-clamp (SEVC) mode. The voltage inputs to the sample and hold circuits of each system were continuously monitored on oscilloscopes to ensure complete settling between current injection cycles; sample rates ranged from 1.3 to $2.0 \mathrm{kHz}$, and output band width was set at $0.3 \mathrm{kHz}$. At the end of the experiment, microelectrodes were withdrawn from the cell, and only those preparations in which both electrodes were within $\pm 5 \mathrm{mV}$ of the bath potential were accepted. Data were digitized, stored, and analyzed on a computer (AT clone) using pCLAMP software (Axon Instruments)

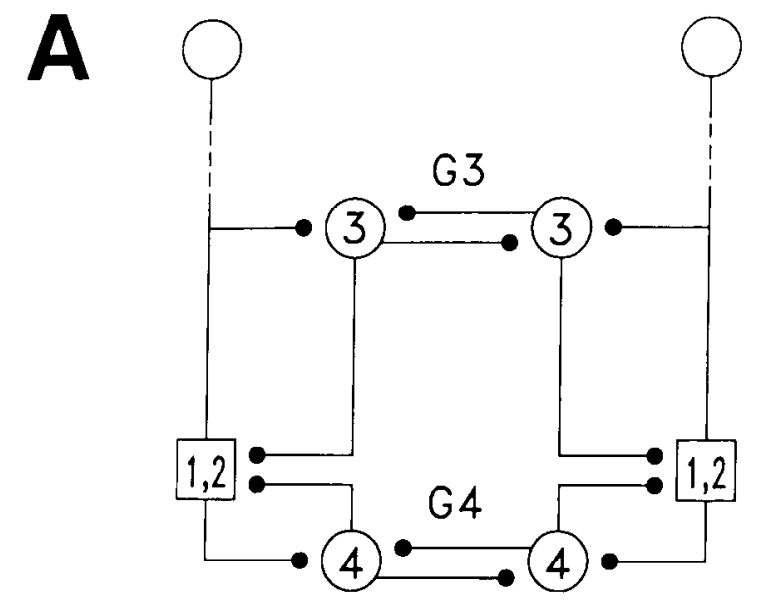

B

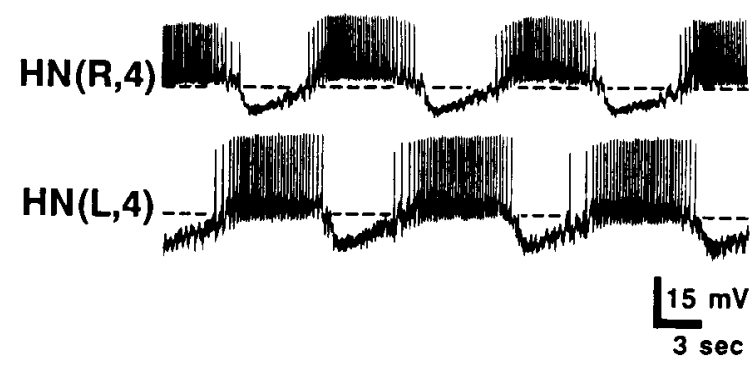

Figure 1. Synaptic connectivity in the heartbeat central oscillator. $A$, Schematic diagram showing the synaptic connections of HN cells in the heartbeat timing oscillator. Open circles represent HN cell bodies numbered by the ganglion in which they reside ( $G 3$ or $G 4)$; smaller solid circles represent inhibitory synaptic conncctions. The HN(1) and HN(2) cells, which have identical connections and electrical properties, are lumped together $(1,2)$. Their primary input regions and spike-initiation zones are located in G4 (open squares) and have therefore been drawn separately from their somata. Synaptic interactions between $\mathrm{HN}(1)$ and $\mathrm{HN}(2)$ cells and ipsilateral $\mathrm{HN}(3)$ or $\mathrm{HN}(4)$ cells can sustain oscillations only when the dominant contralateral reciprocal interactions are eliminated (Peterson, 1983; Calabrese et al., 1989). B. Simultaneous intercellular recordings from 2 reciprocally inhibitory $\mathrm{HN}$ cells of the timing oscillator in an isolated ganglion. Spontaneous activity consists of alternate bursting in normal physiological saline. Dashed lines indicate a membrane potential of $-50 \mathrm{mV}$.

or recorded on a videocassette recorder modified for FM recording (Vetter, model 240).

The typical pulse protocol in the presynaptic cell consisted of 2 depolarizing voltage steps separated by a hyperpolarizing step of equal magnitude and duration. Currents obtained in response to the 2 depolarizing steps were averaged. Unless otherwise indicated, all currents in the presynaptic cell were leak subtracted by addition of the current generated by the intervening hyperpolarizing voltage step. The time between voltage steps was controlled manually; an ensuing stimulus was applied after pre- and postsynaptic currents returned to the original holding level. During off-line analysis, current and voltage records were sometimes filtered using pcLAmp software routines. In all cases, the filter was adjusted so that relevant current or voltage trajectories were unaffected by the smoothing process.

Intraganglionic synaptic contacts between reciprocally inhibitory $\mathrm{HN}$ cells occur at the distal tips of dendritic processes (Tolbert and Calabrese, 1985). Given the rather extensive dendritic tree of the HN cell, this raises questions as to the adequacy of the space clamp obtained with a microelectrode in the cell body. Although there are as yet no quantitative 
data available on the electrotonic length of HN cells, several observations suggest that they may be electrically compact: (1) When bathed in Na-free saline, the input resistance of $\mathrm{HN}$ cells is relatively large (50$60 \mathrm{M} \Omega l$ ). In addition, a variety of voltage-dependent currents whose activation could decrease the membrane resistance of the $\mathrm{HN}$ cells were suppressed. $\mathrm{Na}^{+}$currents were eliminated by recording in $\mathrm{Na}$-free saline, and $I_{h}$ was blocked with extracellular $\mathrm{Cs}^{+}$(Angstadt and Calabrese, 1989). Outward $\mathrm{K}^{+}$currents $\left(I_{\mathrm{K}}\right.$ and $\left.I_{A}\right)$ were partially suppressed with TEA and 4-AP, and those voltages where significant activation of outward currents occurs were avoided. (2) The amplitude of synaptic currents generated in the distal dendrites was easily manipulated by small changes in the holding potential applied at the cell body. Moreover, reversal of synaptic potentials (or currents) was consistently observed to occur at a membrane potential near $-60 \mathrm{mV}$. This value is close to the most negative potential reached by $\mathrm{HN}$ cells during their normal bursting activity ( -55 to $-60 \mathrm{mV}$ ). Such agreement would not be expected if there was a major decrement in the dendritic synaptic potentials as measured at the cell bodies. (3) Other problems associated with spaceclamp failure, such as abrupt and unpredictable changes in ionic current during the voltage commands, were never observed. In addition, our data show that $\mathrm{Ca}^{2+}$ currents activate and inactivate over a physiologically reasonable voltage range. For example, nearly all steady-state inactivation of $\mathrm{Ca}^{2+}$ currents is removed by voltage steps to $-70 \mathrm{mV}$. Clearly, modeling studies of $\mathrm{HN}$ cells are needed for a more quantitative assessment of the errors that may occur during voltage clamp of HN cells. Nevertheless, the above observations suggest that no serious problems with voltage control of $\mathrm{HN}$ cells are occurring under the conditions of these experiments.

\section{Results}

Graded synaptic transmission between reciprocally inhibitory $H N$ cells

Graded synaptic transmission between HN cells in G3 and G4 was examined in experiments in which $1 \mathrm{HN}$ cell was voltage clamped at $-60 \mathrm{mV}$ and stepped through a series of more depolarized potentials. The contralateral $\mathrm{HN}$ cell was held at a membrane potential between -40 and $-30 \mathrm{mV}$ in either SEVC mode to record postsynaptic currents or in DCC mode to record postsynaptic potentials. Synaptic transmission was examined in salines containing either $2 \mathrm{~mm}$ extracellular $\mathrm{Ca}^{2+}(n=8)$ or 5 $\mathrm{mm}$ extracellular $\mathrm{Ca}^{2+}(n=19)$. In some experiments, the postsynaptic responses were observed in both SEVC and DCC. However, in other experiments, the postsynaptic cell was examined in only 1 of these recording modes. Thus, in $2 \mathrm{~mm} \mathrm{Ca}^{2+}$, there were 5 experiments in which inhibitory postsynaptic currents (IPSCs) were recorded and 6 experiments where IPSPs were recorded. In $5 \mathrm{mM} \mathrm{Ca}^{2+}$, there were 14 preparations where IPSCs were recorded and 11 preparations where IPSPs were recorded.

Figure 2 illustrates data from a preparation bathed in $2 \mathrm{~mm}$ $\mathrm{Ca}^{2+}$. In Figure $2 A$, traces on the left are the inward currents generated in the presynaptic HN cell by a voltage step to the potential indicated at the left of each record. Traces on the right are the outward synaptic currents (IPSCs) recorded in the contralateral $\mathrm{HN}$ cell, which was voltage clamped at $-35 \mathrm{mV}$. The presynaptic voltage steps are shown at the top of each set of current traces. The presynaptic inward currents elicited by the smaller depolarizations are relatively flat and persist for the duration of the voltage step. Currents elicited by larger voltage steps have a biphasic wave form consisting of a relatively large transient component of inward current followed by a persistent component of smaller amplitude. For convenience, we will refer to these components as the transient and persistent $\mathrm{Ca}^{2+}$ currents, respectively. In Figure $2 B$, the pre- and postsynaptic currents evoked by the voltage step to $-35 \mathrm{mV}$ are shown at higher gain. Arrows indicate how peak current and the current at $1 \mathrm{sec}$ (defined as the persistent current) were measured relative to the holding current level (indicated by the dashed line). Note that outward synaptic current, though small, clearly persists for the duration of the presynaptic voltage step.

Figure $2 C$ illustrates the relationship between presynaptic command potential and peak (squares) and persistent (diamonds) presynaptic inward currents. From a holding potential of $-60 \mathrm{mV}$, inward currents were consistently elicited by the smallest voltage step applied (to $-50 \mathrm{mV}$ ). The amplitude of both the peak and the persistent currents increased approximately linearly as a function of membrane potential over the voltage range examined. However, current amplitudes tended to level off and then decrease positive to about $-35 \mathrm{mV}$. This decrease may be due to interference from outward $\mathrm{K}^{+}$currents, which have a threshold between -35 and $-30 \mathrm{mV}$. For this reason, presynaptic voltage steps positive to $-32 \mathrm{mV}$ are not presented. Figure $2 D$ illustrates the relationship between presynaptic potential and the amplitude of postsynaptic currents in the contralateral $\mathrm{HN}$ cell. In this preparation, the threshold for IPSCs was $-42.5 \mathrm{mV}$. In most preparations, threshold was $-45 \mathrm{mV}$, though in a few cases, presynaptic voltage steps to $-47.5 \mathrm{mV}$ elicited measurable synaptic responses. Synaptic responses were never observed in the absence of presynaptic current. Although these experiments were performed in saline with a slightly elevated extracellular $\mathrm{Ca}^{21}$ concentration $(2 \mathrm{~mm}$ vs normal $\left[\mathrm{Ca}^{2+}\right]_{o}$ of $1.8 \mathrm{~mm}$ ), the amplitude of synaptic currents obtained in most preparations was relatively small. We therefore decided to increase the concentration of $\mathrm{Ca}^{2+}$ in the hopes of increasing the amplitude of both pre- and postsynaptic currents.

Figure 3 illustrates data from a preparation bathed in $5 \mathrm{~mm}$ $\mathrm{Ca}^{2+}$. As in the previous figure, traces on the left are the inward currents generated in the presynaptic $\mathrm{HN}$ cell by a series of depolarizing voltage steps. In Figure $3 A$, traces on the right show the postsynaptic currents recorded in the contralateral $\mathrm{HN}$ cell clamped at a holding potential of $-35 \mathrm{mV}$. In Figure $3 B$, the same $\mathrm{HN}$ cell was recorded in DCC mode and held at $-35 \mathrm{mV}$ by maintained current injection. The top set of traces in each panel show the voltage steps applied to the presynaptic cell. As expected, both the pre- and postsynaptic currents recorded in $5 \mathrm{mM} \mathrm{Ca}^{2+}$ were larger than those obtained in $2 \mathrm{mM} \mathrm{Ca}^{2+}$. In addition, the distinction between the transient and the persistent components of presynaptic inward current was particularly evident.

Figure $3 C$ shows the relationship between presynaptic potential and the amplitude of presynaptic inward currents (averaged values from the trials in Fig. $3 A, B$ ). The relationship between presynaptic potential and peak current is somewhat steeper than in $2 \mathrm{mM} \mathrm{Ca}^{2+}$, and the peak currents clearly approach a maximum near $-35 \mathrm{mV}$. As in $2 \mathrm{mM} \mathrm{Ca}^{2+}$, the smallest voltage steps (to $-50 \mathrm{mV}$ ) consistently elicited inward current in the presynaptic HN cell $(n=22)$. In separate experiments using a holding potential of $-70 \mathrm{mV}(n=10)$, the activation threshold for inward currents occurred at $-60 \mathrm{mV}(n=6),-55 \mathrm{mV}(n=3)$, or $-50 \mathrm{mV}(n=1)$.

Figure $3 D$ illustrates the relationship between presynaptic potential and postsynaptic current. As in $2 \mathrm{mM} \mathrm{Ca}^{2+}$, IPSC amplitude is graded with presynaptic command potential. IPSCs were usually observed following presynaptic voltage steps to $-45 \mathrm{mV}$. The larger IPSCs are hiphasic, exhibiting an early peak followed by a more slowly decaying component that often persisted for the duration of the presynaptic voltage step. In Figure $3 E$, presynaptic potential is plotted versus the amplitude of postsynaptic potentials recorded in DCC. In this case, the 


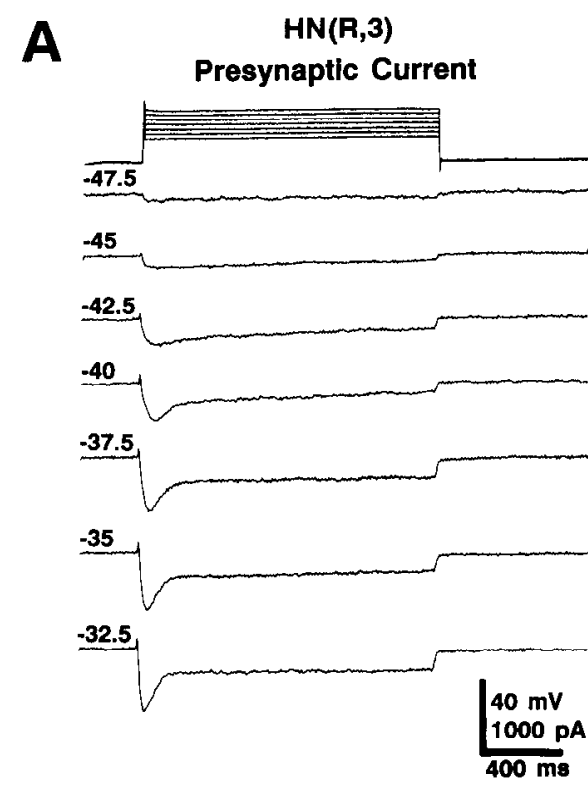

B
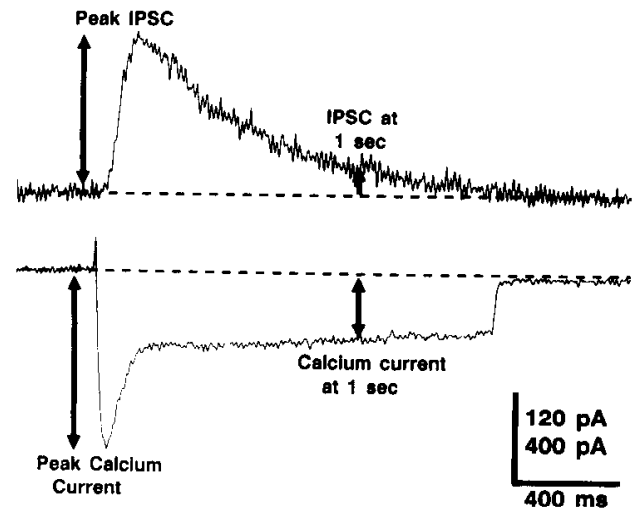

HN(L,3)
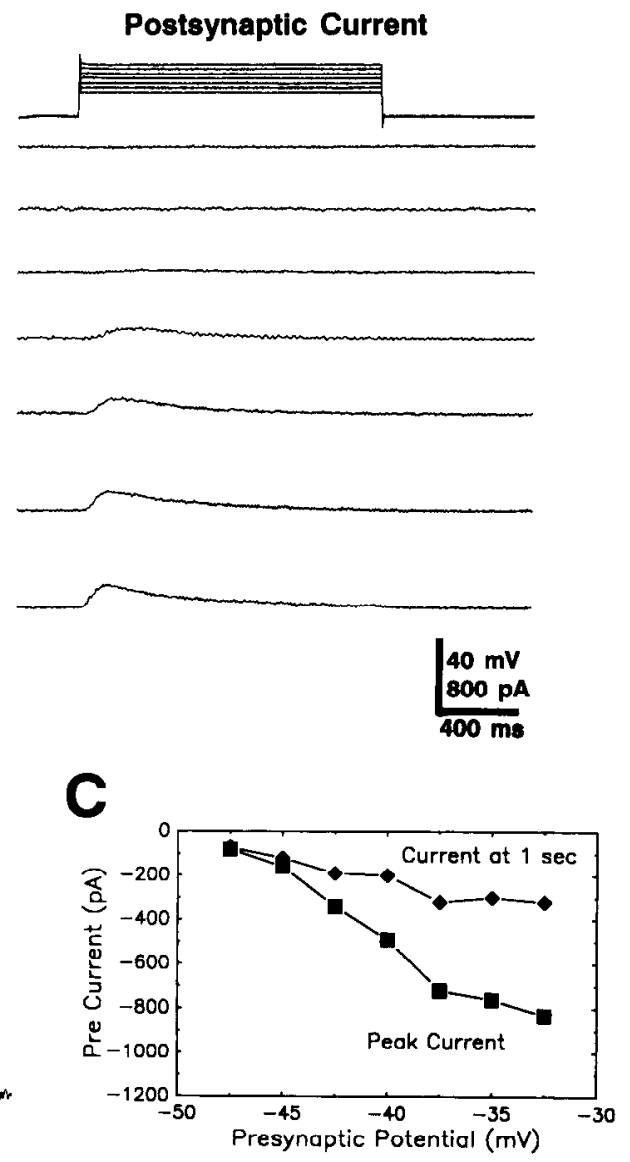

D

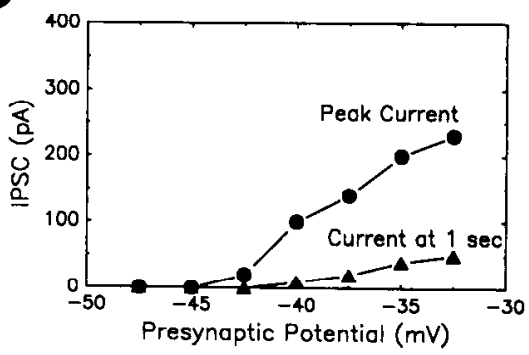

Figure 2. Presynaptic and postsynaptic currents recorded in $\mathrm{Na}$-free saline containing $2 \mathrm{~mm} \mathrm{Ca}{ }^{2+} . A$, Traces on the left show inward currents in an IIN $(R, 3)$ cell elicited by voltage steps from a holding potential of $-60 \mathrm{mV}$ to the potential indicated at the left of each record. Traces on the right show the corresponding IPSCs recorded in the $\mathrm{HN}(\mathrm{L}, 3)$ cell in SEVC at a holding potential of $-35 \mathrm{mV}$. Top traces on each side show the presynaptic voltage steps. Action potentials were eliminated by bathing in $\mathrm{Na}$-free saline. A hyperpolarization-activated inward current $\left(I_{h}\right)$ was blocked by addition of $4 \mathrm{~mm} \mathrm{Cs}{ }^{+}$ (Angstadt and Calabrese, 1989). In addition, outward currents were suppressed with extracellular 4-AP and intracellular TEA (see Materials and Methods). B, IPSC (upper trace) and presynaptic current (lower trace) for the voltage step to $-35 \mathrm{mV}$ shown at higher gain. Both peak and persistent currents were measured relative to the holding current level (marked by dashed line). Peak currents were defined as the maximum current regardless of the time from the beginning of the presynaptic voltage step. Persistent currents were defined as currents measured after $1 \mathrm{sec}$ (arrows). Thus, for a flat current, the peak and persistent currents would be equivalent. $C$, Graph showing the amplitude of peak (squares) and persistent (diamonds) inward currents in the presynaptic cell versus command potential. $D$, Graph of the IPSC amplitudes from $A$ plotted against presynaptic command potential. Circles show the peak amplitude of the IPSC, and triangles show the amplitude of the IPSC at $1 \mathrm{sec}$. threshold for IPSPs was $-45 \mathrm{mV}$, though thresholds as low as $-47.5 \mathrm{mV}$ were observed in other preparations. It is interesting to note that, in 3 preparations, a small depolarization was mcasured in the postsynaptic cell (in DCC) during the presynaptic voltage step to $-50 \mathrm{mV}$. This result may have reflected the weak electrotonic coupling between contralateral $\mathrm{HN}$ cells (Thompson and Stent, 1976b). The presence of this coupling may obscure the measurement of inhibitory postsynaptic responses near threshold, resulting in an underestimate of the true synaptic threshold. Above threshold, IPSP amplitudes were graded with presynaptic potential. For all preparations in $5 \mathrm{~mm}$ $\mathrm{Ca}^{2+}$ combined, a 4-5-mV presynaptic depolarization elicited a 10 -fold increase in the peak amplitude of the IPSP. A 10 -fold change in the IPSP measured at $1 \mathrm{sec}$, however, required a presynaptic depolarization of 7-9 $\mathrm{mV}$. These relationships are steeper than those observed in $2 \mathrm{mM} \mathrm{Ca}^{2+}$, where $8-11 \mathrm{mV}$ and $12-15 \mathrm{mV}$ presynaptic depolarizations produced 10 -fold changes in the peak IPSP and the IPSP measured at $1 \mathrm{sec}$, respectively.
In Figure $2 F$, the amplitude of the peak and persistent IPSCs were plotted versus the amplitudes of the peak and persistent presynaptic currents, respectivcly. In both cases, an approximately linear relationship was obtained between these 2 parameters in the voltage range examined.

\section{Reversal potential of synaptic currents}

The synaptic reversal potential was determined by recording the postsynaptic currents elicited by a standard presynaptic voltage step at a variety of postsynaptic holding potentials. In Figure 4 , the top trace shows the presynaptic current (average response of all trials) recorded during a voltage step from -60 to -35 $\mathrm{mV}$. The lower set of traces shows the corresponding IPSCs recorded at 7 different postsynaptic holding potentials. At holding potentials positive to $-60 \mathrm{mV}$, the postsynaptic currents are outward. Negative to $-60 \mathrm{mV}$, the currents are reversed and become inward. We obtained similar results in 3 additional preparations where postsynaptic currents were recorded in volt- 


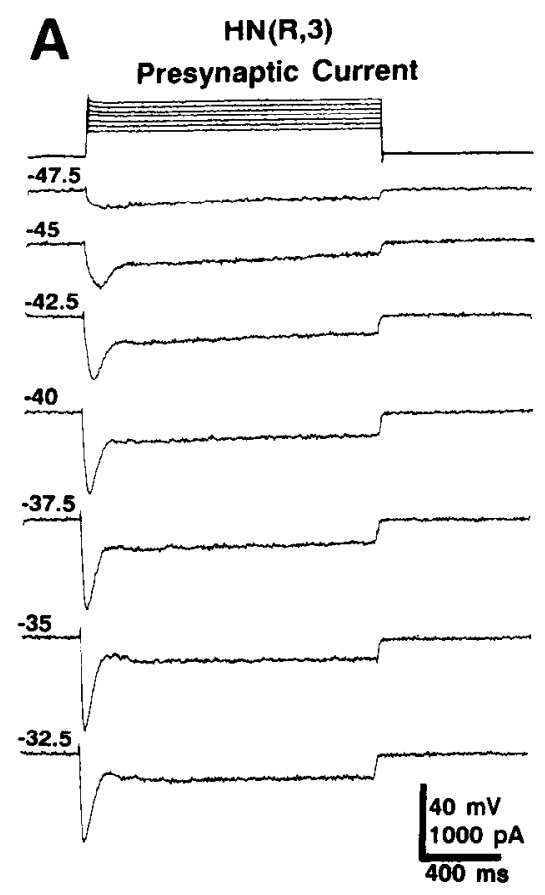

B

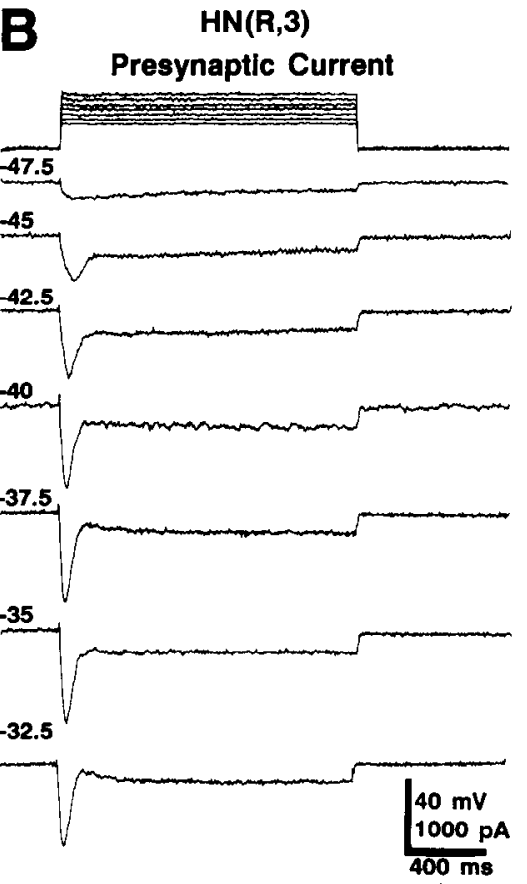

HN(L,3)

Postsynaptic Current

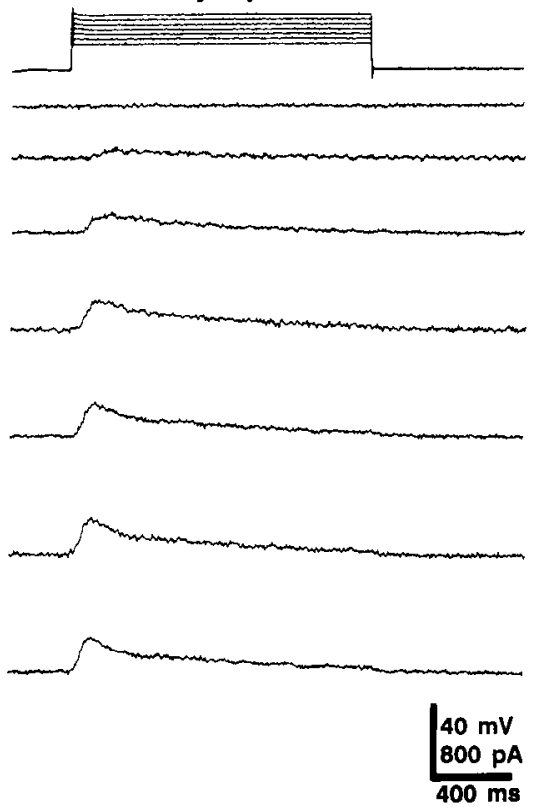

HN (L,3)

Postsynaptic Potential
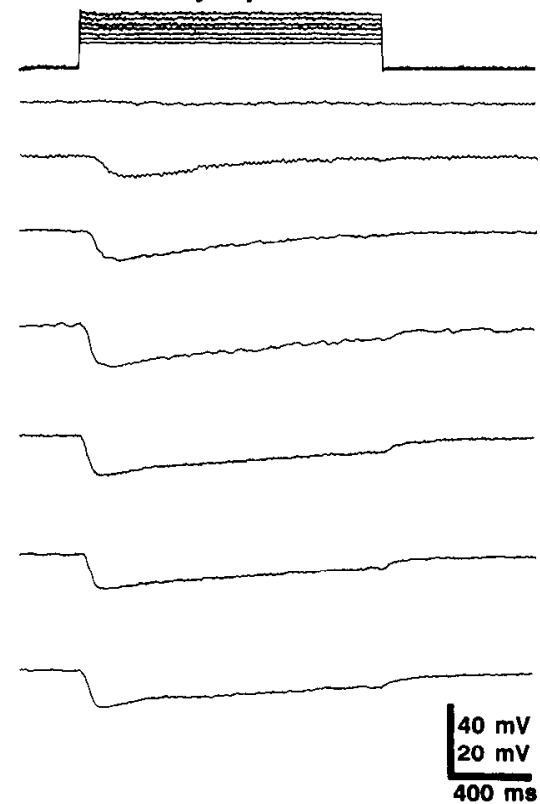

C

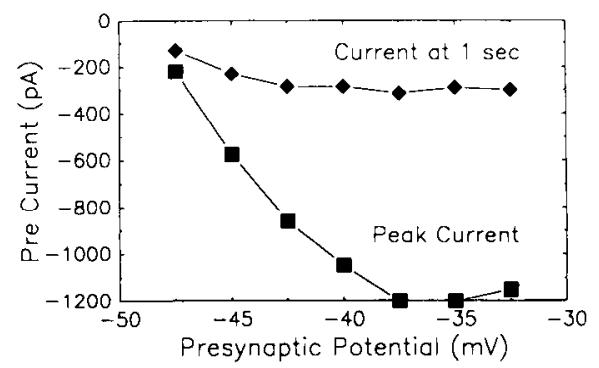

D

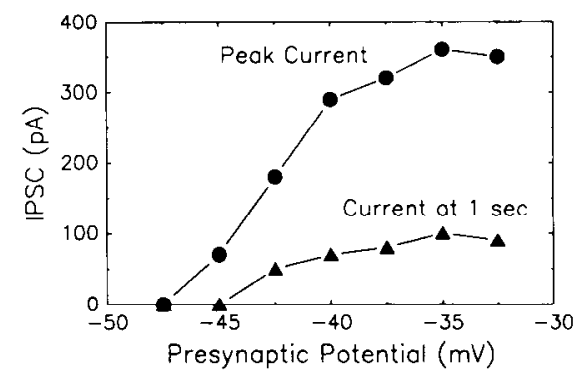

E

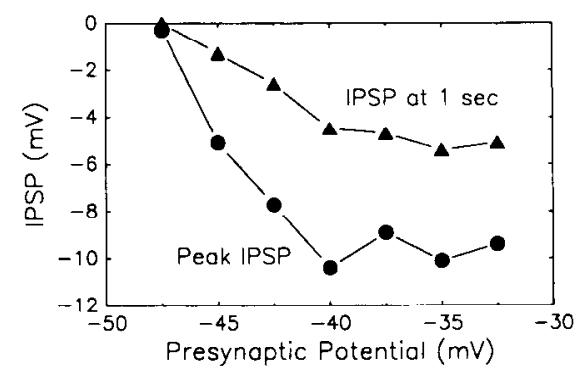

$\mathbf{F}$

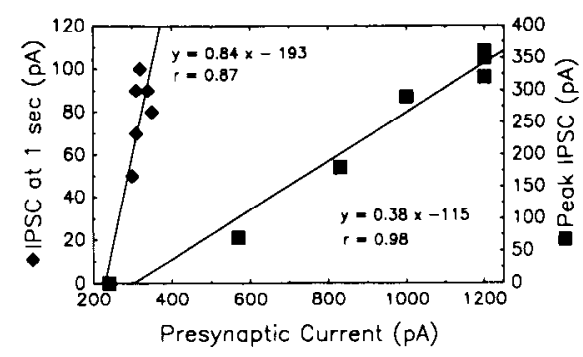

Figure 3. Presynaptic currents and postsynaptic responses obtained in Na-free saline containing $5 \mathrm{~mm} \mathrm{Ca}^{2+}$. A, Traces on the left show inward currents in an $H N(R, 3)$ cell elicited by voltage steps from a holding potential of $-60 \mathrm{mV}$ to the potential indicated at the left of each record. Traces on the right show the corresponding IPSCs in the HN(L,3) cell recorded in SEVC at a holding potential of $-35 \mathrm{mV}$. Top set of traces on each side shows the presynaptic voltage steps. $B$, Same cells as in $A$ but in another trial. In this case, the postsynaptic HN cell was placed in DCC to record IPSPs. $C$, Graph showing peak (squares) and persistent (diamonds) inward currents in the presynaptic cell versus command potential. Values shown represent the average of currents obtained in trials $A$ and $B . D$. Graph of the IPSC amplitudes from $A$ plotted against presynaptic command potential. Circles show the peak amplitude of the IPSC, and triangles show the IPSC amplitude at $1 \mathrm{sec}$. $E$, Graph of the IPSP amplitudes from $B$ plotted against presynaptic command potential. Circles show the peak amplitude of the IPSP, and triangles show the amplitude of the IPSP at 1 sec. $F$, Graph of the peak IPSCs (squares) and the IPSCs at $1 \mathrm{sec}$ (diamonds) versus the peak presynaptic currents and presynaptic currents measured at $1 \mathrm{sec}$, respectively. Note the different scales for the 2 vertical axes. The data points were fit by linear regression. 


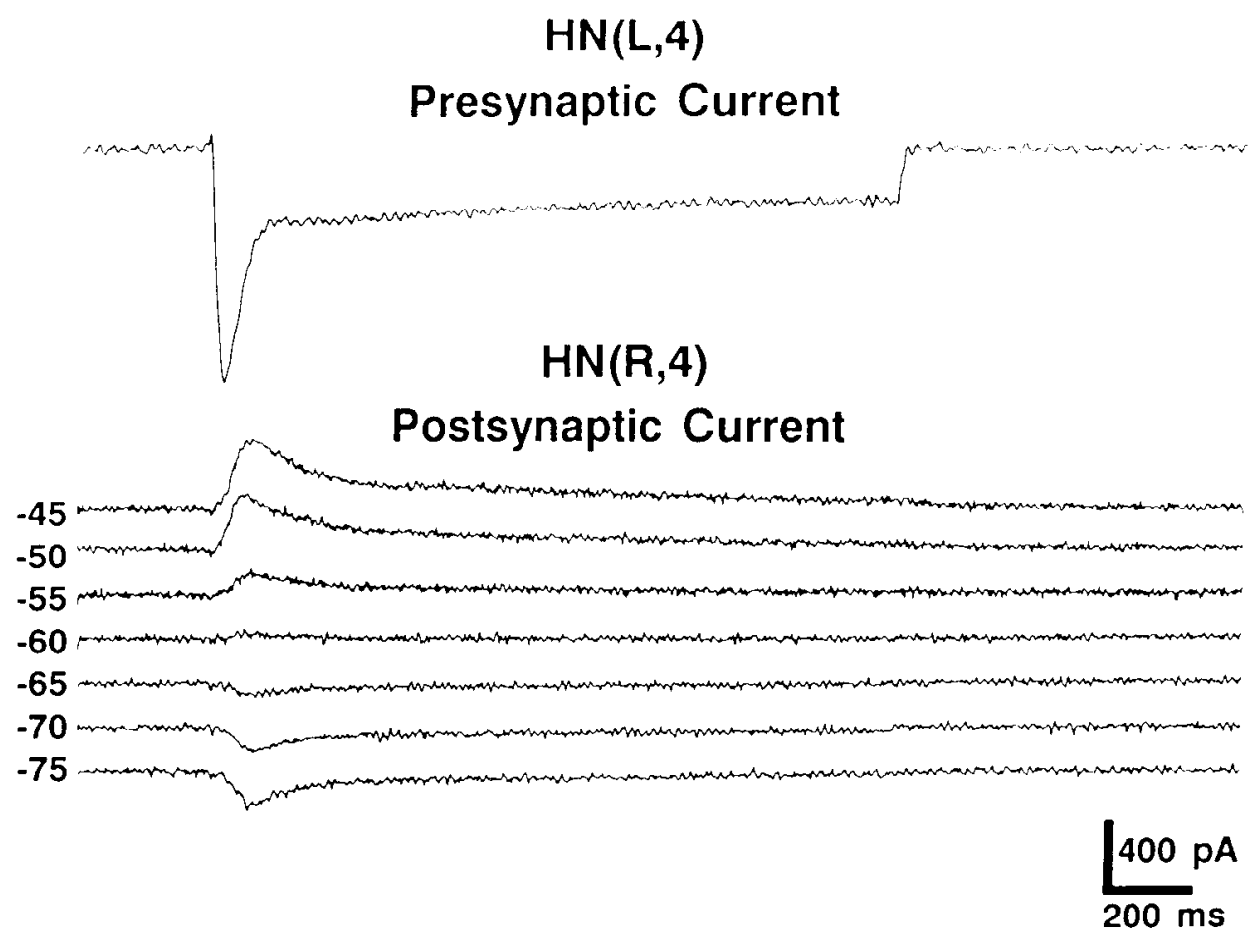

Figure 4. Reversal of synaptic currents in the postsynaptic HN cell. The top trace shows the average inward current recorded in an $\mathrm{HN}(\mathrm{L}, 4)$ cell in response to a voltage step from -60 to $-35 \mathrm{mV}$. The lower set of traces illustrates the corresponding postsynaptic currents in the $\operatorname{HN}(R, 4)$ cell obtained at different holding potentials (indicated to the left of the individual records). age clamp and in 2 preparations where we recorded reversal of the IPSPs in discontinuous current clamp.

\section{Transient and persistent inward currents are correlated with different components of the postsynaptic response}

The discovery of 2 kinetically distinct inward currents raises the issue of whether 1 or both of these currents are directly involved in the release of neurotransmitter. The relative contribution of the transient and persistent inward currents to postsynaptic responses was tested by comparing the effects of relatively long presynaptic voltage steps, which elicit both the transient and persistent inward currents, to those produced by brief voltage steps, which elicit primarily the transient inward current. Figure 5 shows the presynaptic currents and postsynaptic potentials (Fig. 5A) and postsynaptic currents (Fig. $5 B$ ) elicited by $1.5-\mathrm{sec}$ or 150 -msec presynaptic voltage steps. The postsynaptic responses to bricf presynaptic voltage steps consistently exhibit a faster rate of decay than those produced during the prolonged voltage steps $(n=7)$. Thus, in the absence of the persistent inward current, the prolonged component of the postsynaptic response is eliminated. In this experiment, the rate of decay of the postsynaptic current following the brief voltage step is described well by a single exponential process with a time constant of about $100 \mathrm{msec}$. In contrast, at least 2 exponential processes are required to fit the decay of the postsynaptic current during the long voltage step, one with a time constant of about 100 msec, and the other with a time constant of $1 \mathrm{sec}$ or more. Similar results were obtained in 2 other preparations where IPSCs were recorded. Thus, the transient and persistent inward currents each appear to be correlated with separate components of transmitter release, resulting in a biphasic wave form of the postsynaptic response during prolonged presynaptic depolarization.
Waning of graded synaptic transmission during prolonged presynaptic voltage steps

A typical HN cell burst in normal saline lasts for at least $5 \mathrm{sec}$. We wished to determine the degree to which postsynaptic responses decay during presynaptic voltage steps of comparable durations. Figure 6 compares the time course of presynaptic current and postsynaptic potential (Fig. 6A) and postsynaptic current (Fig. 6B) during 5-sec-duration voltage steps. The 2 components of presynaptic current are easily distinguished using this protocol, with a large transient inward current followed by the slow decay of the persistent inward current. The decay of postsynaptic currents was again best described by at least 2 exponential processes $(n=11)$. The mean time constants were $103 \pm 29( \pm \mathrm{SD})$ and $1285 \pm 474 \mathrm{msec}$. In 10 out of 12 preparations, the postsynaptic current was observed to decay completely during the presynaptic voltage step. In 2 preparations, the postsynaptic response appeared to decay to a small but steady level of outward current.

\section{Insensitivity of presynaptic and postsynaptic currents to FMRFamide}

The molluscan cardioexcitatory peptide Phe-Met-Arg-Phe-amide (FMRFamide) decreases the cycle period of the leech heartbeat central pattern generator (Kuhlman et al., 1985). However, hath application of FMRFamide $(1 \mu \mathrm{M})$ had no effect on (1) the amplitude or time course of the transient and persistent $\mathrm{Ca}^{2+}$ currents, (2) the amplitude or time course of IPSPs or IPSCs, or (3) the holding current $(n=6)$. Previous studies also failed to demonstrate an effect of FMRFamide on the hyperpolarization-activated inward current $I_{h}$ (Angstadt and Calabrese, 1989). The failure to observe effects of FMRFamide on inward currents in HN cells suggests that outward currents, which have not yet 

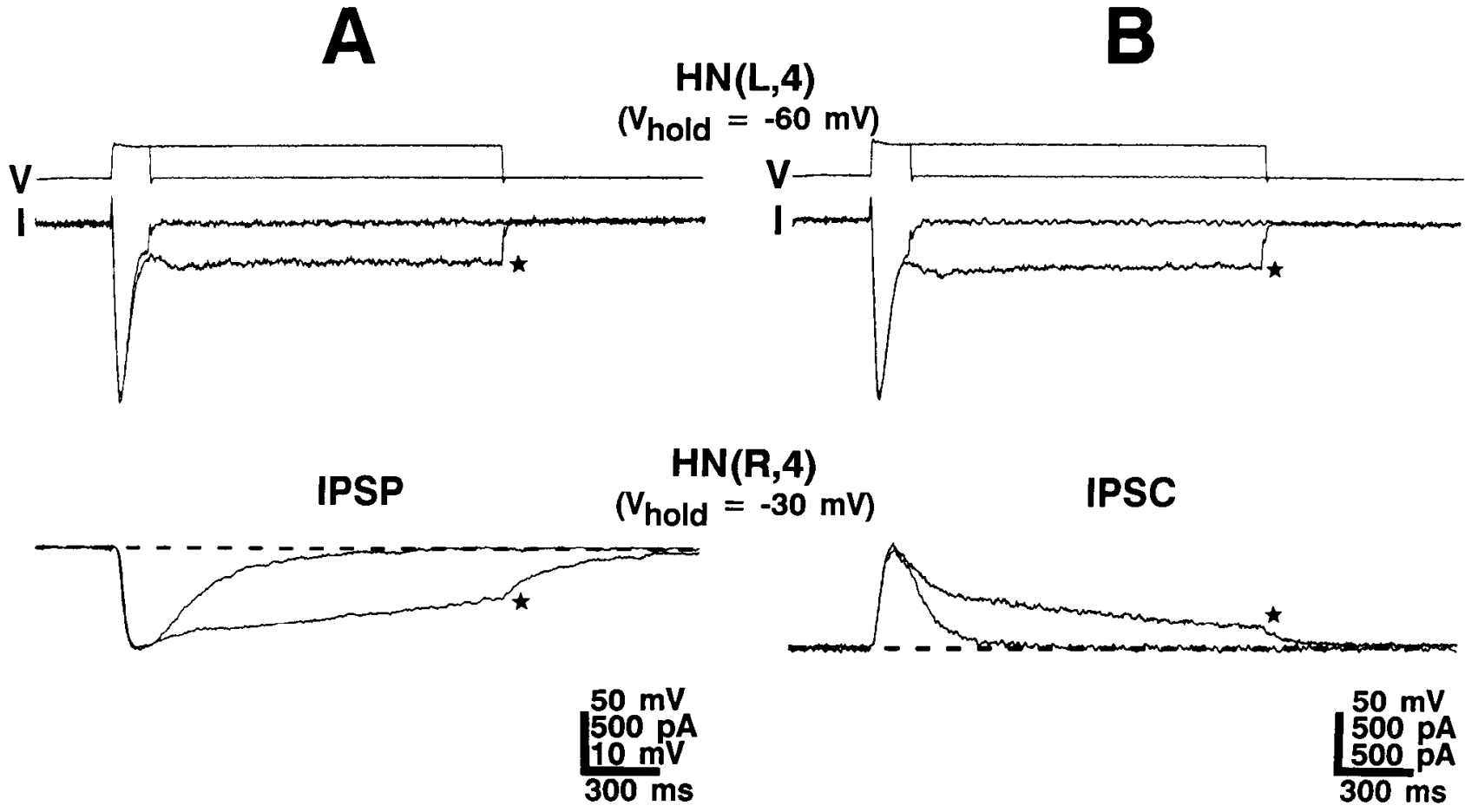

Figure 5. Comparisons of the presynaptic currents and postsynaptic responses elicited by 1.5 -sce or 150 -msec presynaptic voltage steps from -60 to $-35 \mathrm{mV}$. Top traces in $A$ and $B$ show the voltage steps $(V)$ and inward currents $(I)$ recorded in the presynaptic cell. Bottom traces illustrate the postsynaptic potentials $(A)$ or postsynaptic currents $(B)$ recorded in the contralateral HN cell. Stars mark the traces corresponding to the 1.5 -sec voltage steps. Dashed lines in this and subsequent figures provide a reference for the holding potential or holding current just prior to the presynaptic voltage step. $A$ and $B$ are from the same preparation.

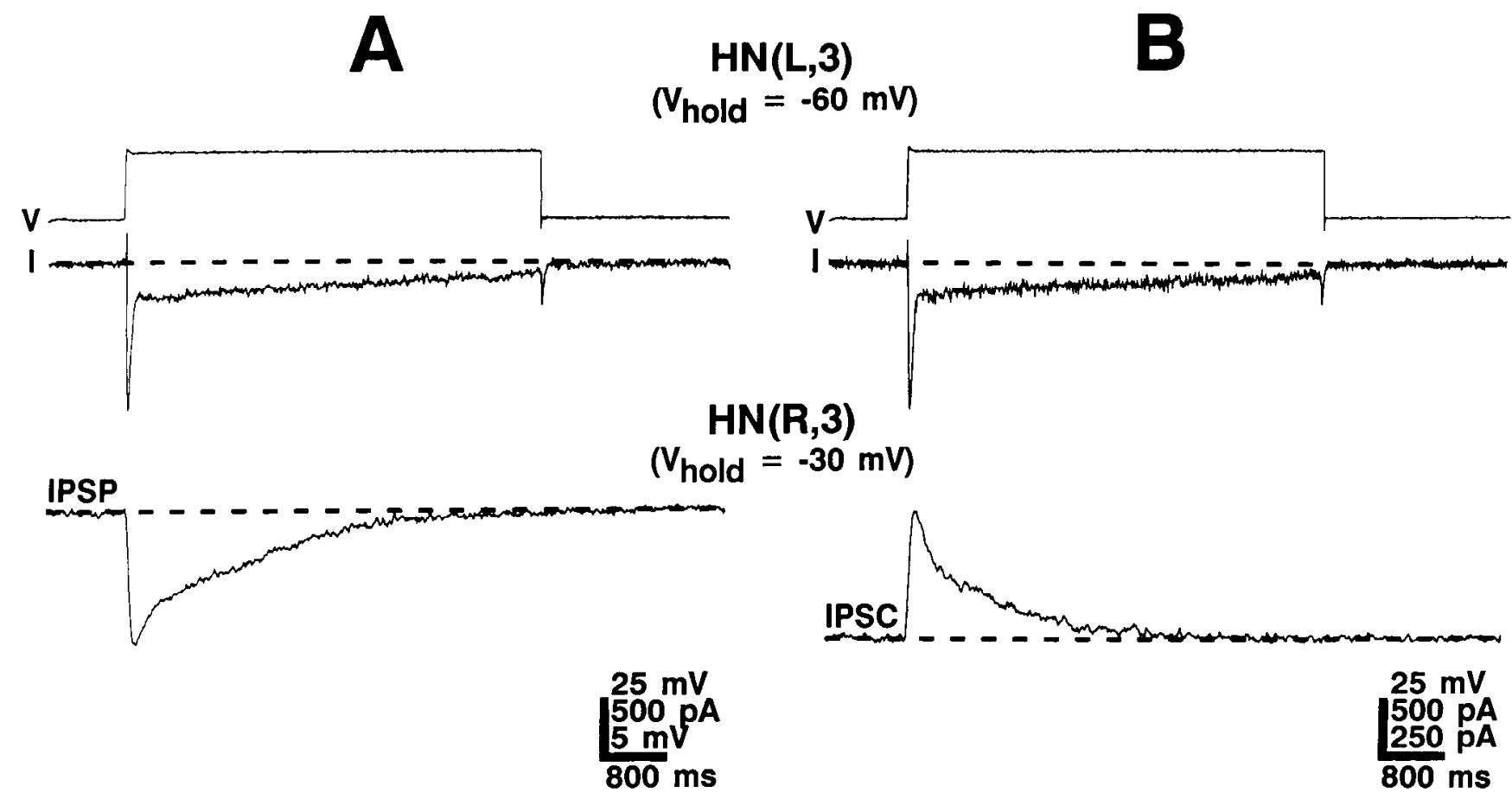

Figure 6. Waning of synaptic transmission during prolonged voltage steps. A, Presynaptic voltage (top trace) and current (middle trace) during a step from -60 to $-35 \mathrm{mV}$ in an HN(L,3) cell. Note the characteristic transient inward current followed by the persistent inward current that decays at a much slower rate. The lower trace shows the postsynaptic potential produced in the HN(R,3) cell. Following a large initial peak, the IPSP amplitude steadily declined during the 5 -sec stimulus. $B$. Same preparation as in $A$ in another trial in which the postsynaptic cell was voltage clamped at $-30 \mathrm{mV}$. Outward synaptic current also exhibits a significant decay during the presynaptic voltage step. 


\section{Control}
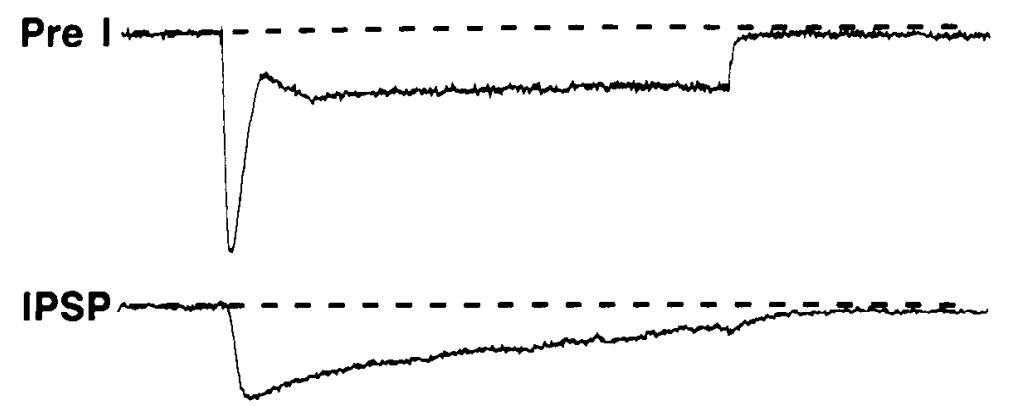

\section{Cobalt}

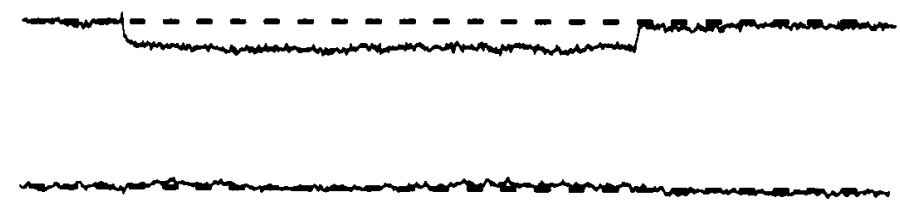

Figure 7. Substitution of $\mathrm{Co}^{2+}$ for $\mathrm{Ca}^{2+}$ suppresses inward currents and eliminates synaptic transmission. Three panels are illustrated: control $(5 \mathrm{~mm}$ $\left.\mathrm{Ca}^{2+}\right)$, cobalt $\left(\mathrm{Ca}^{2+}\right.$ replaced with an equimolar concentration of $\left.\mathrm{Co}^{2+}\right)$, and wash ( $\left.5 \mathrm{~mm} \mathrm{Ca}^{2+}\right)$. The upper trace in each panel shows the presynaptic current recorded in an $H N(R, 4)$ cell during a voltage step from -60 to $-35 \mathrm{mV}$. The lower traces show the postsynaptic potential recorded in the $\mathrm{HN}(\mathrm{L}, 4)$ cell at a holding potential of $-35 \mathrm{mV} . \mathrm{Co}^{2+}$ saline contained 2 m $\mathrm{mGTA}$. been examined in detail, may be modulated by the peptide. This hypothesis is consistent with the observation that bath application of 4-AP ( $5 \mathrm{mM}$ ), which suppresses an $I_{A}$-like current in $\mathrm{HN}$ cells, also decreases the cycle period of reciprocally inhibitory $\mathrm{HN}$ cells in isolated ganglia ( $n=6$; data not shown).

Calcium dependence of inward currents and graded synaptic transmission

Figure 7 illustrates the effect of replacing $5 \mathrm{~mm}$ extracellular $\mathrm{Ca}^{2+}$ in the saline with $5 \mathrm{~mm} \mathrm{Co}^{2+}$ and $2 \mathrm{~mm}$ EGTA. Superfusion with cobalt saline blocks inhibitory synaptic transmission between HN cells and strongly suppresses the presynaptic inward currents. In each panel, the upper trace shows the presynaptic current elicited by a 1.5 -sec voltage step from -60 to $-35 \mathrm{mV}$, and the lower trace, the resulting IPSP in the contralateral HN cell. The top panel shows the preparation in $5 \mathrm{~mm} \mathrm{Ca}^{2+}$. The middle panel shows the same preparation approximately $2 \mathrm{~min}$ after superfusing with cobalt saline. The presynaptic currents were strongly suppressed, and the IPSP was eliminated. Inward presynaptic currents and the IPSP show partial recovery after returning to $5 \mathrm{mM} \mathrm{Ca}^{2+}$ (bottom panel). The small inward pre- synaptic current remaining in cobalt saline may reflect an incomplete substitution of $\mathrm{Co}^{2+}$ for $\mathrm{Ca}^{2+}$ ions in the neuropil. In other preparations bathed in cobalt saline for longer times (5$10 \mathrm{~min}$ ), inward currents disappear completely (not shown). However, in these cases, it was difficult to obtain good recovery of inward currents or postsynaptic responses after washing.

We further tested the ionic dependence of the inward currents by replacing $\mathrm{Ca}^{2+}$ with a variety of divalent ions. Figure 8 illustrates inward currents evoked at the offset of hyperpolarizing prepulses in $\mathrm{Na}$-free saline containing $\mathrm{Ca}^{2+}$ versus $\mathrm{Co}^{2+}$ (Fig. $8 A ; n=4$ ), $\mathrm{Sr}^{2+}$ versus $\mathrm{Ni}^{2+}$ (Fig. $8 B ; n=2$ ), or $\mathrm{Ba}^{2+}$ versus $\mathrm{Mn}^{2+}$ (Fig. $8 C ; n=4$ ). In these experiments, a single $\mathrm{HN}$ cell was voltage clamped at a relatively depolarized holding potential $(-40 \mathrm{mV})$, where $\mathrm{Ca}^{2+}$ currents are inactivated. A series of hyperpolarizing voltage steps (prepulses) to more negative membrane potentials was applied to remove steady-state inactivation. Inward $\mathrm{Ca}^{2+}$ currents were subsequently activated upon return to the holding potential, and their peak amplitude was plotted versus prepulse potential. Traces to the right of each graph illustrate the currents obtained during and after prepulses to $-80 \mathrm{mV}$. The data show that inward currents are elicited at 

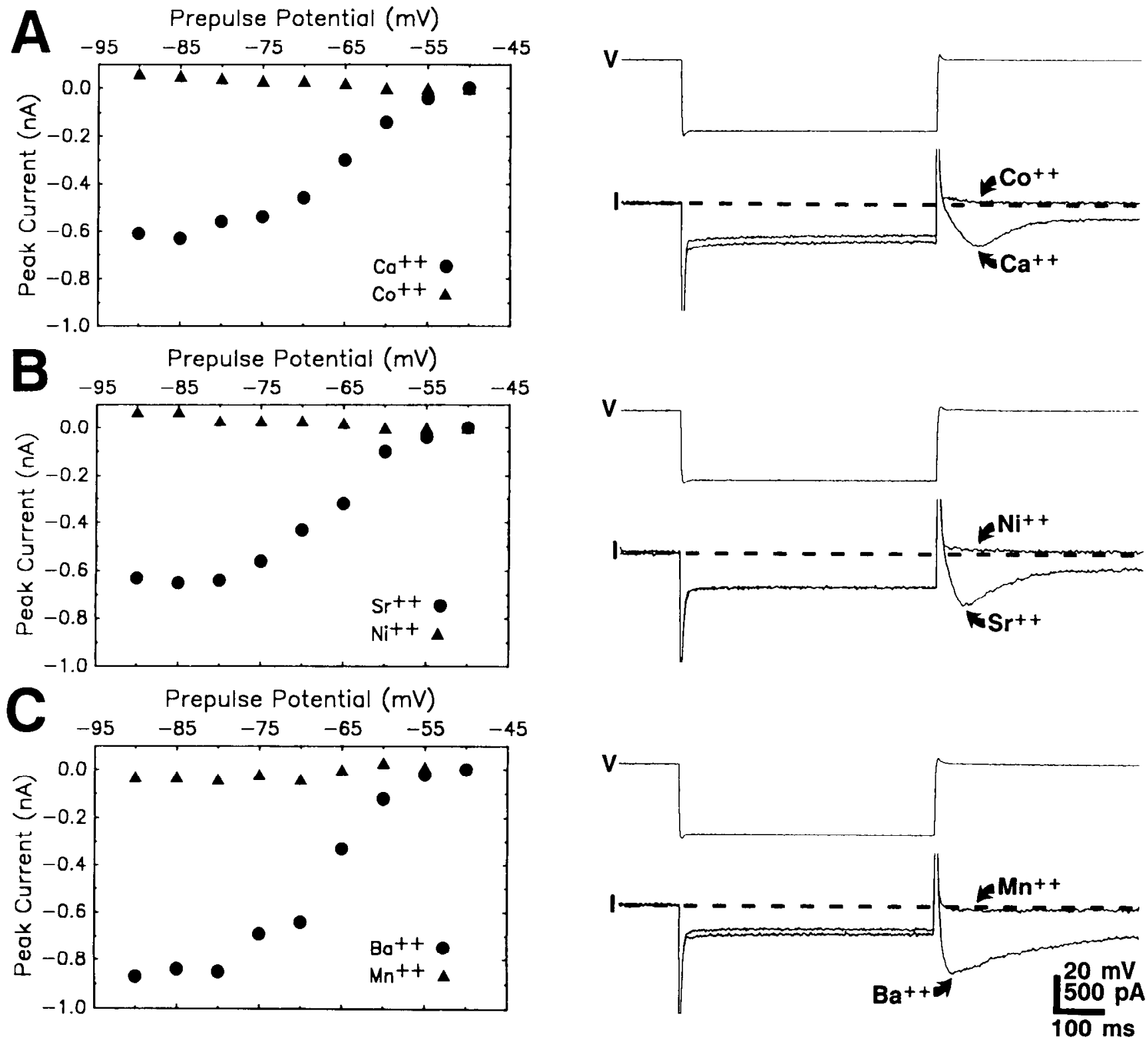

Figure 8. Ionic dependence of inward currents obtained in Na-free saline. Plots illustrate the peak inward current recorded at the offset of hyperpolarizing voltage steps (prepulses) from the holding potential of $-45 \mathrm{mV}$ to a series of more negative potentials. Traces on the right show the actual currents recorded following prepulses to $-80 \mathrm{mV}$ (no leak subtraction). $A$. Currents obtained in $5 \mathrm{~mm} \mathrm{Ca}{ }^{2+}$ versus $5 \mathrm{~mm} C \mathrm{o}^{2+} . B$, Currents obtained in $5 \mathrm{mM} \mathrm{Sr}^{2+}$ versus $5 \mathrm{mM} \mathrm{Ni}^{2+}$. $C$, Currents obtained in $5 \mathrm{~mm} \mathrm{Ba}^{2+}$ versus $5 \mathrm{mM} \mathrm{Mn}^{2+}$. Data in $A-C$ are from 3 different preparations.

the step offset in the presence of $\mathrm{Ca}^{2+}, \mathrm{Sr}^{2+}$, or $\mathrm{Ba}^{2+}$ ions, but are strongly suppressed when these ions are replaced with calcium channel blockers. The small inward currents remaining in $\mathrm{Mn}^{2+}$ saline may reflect incomplete block, or, possibly, a slight permeability to $\mathrm{Mn}^{2+}$ ions, as has been reported in other systems (Nelson, 1986). The suppression of inward currents with $\mathrm{Ca}^{2+}$ channel blockers does not result from a small shift in the threshold for current activation, because inward currents were never revealed at more depolarized holding potentials (data not shown). These results therefore support the conclusion that both the transient and the persistent inward currents recorded in $\mathrm{Na}$-free saline are carried by $\mathrm{Ca}^{2+}$.

\section{Steady-state inactivation of calcium currents}

We examined the steady-state inactivation of $\mathrm{Ca}^{2+}$ currents by stepping from a relatively depolarized holding potential (e.g., $-40 \mathrm{mV}$ ) to a series of more negative command potentials (to remove inactivation). Following the offset of a $2-\mathrm{sec}$ hyperpolarizing prepulse, the peak inward current (representing the transient $\mathrm{Ca}^{2+}$ current) and the inward current $400 \mathrm{msec}$ after step offset (representing the persistent $\mathrm{Ca}^{2+}$ current) were measured relative to the initial holding current. These data were subsequently normalized to the largest current obtained within each group and plotted against prepulse potential. Figure $9 A$ illus- 


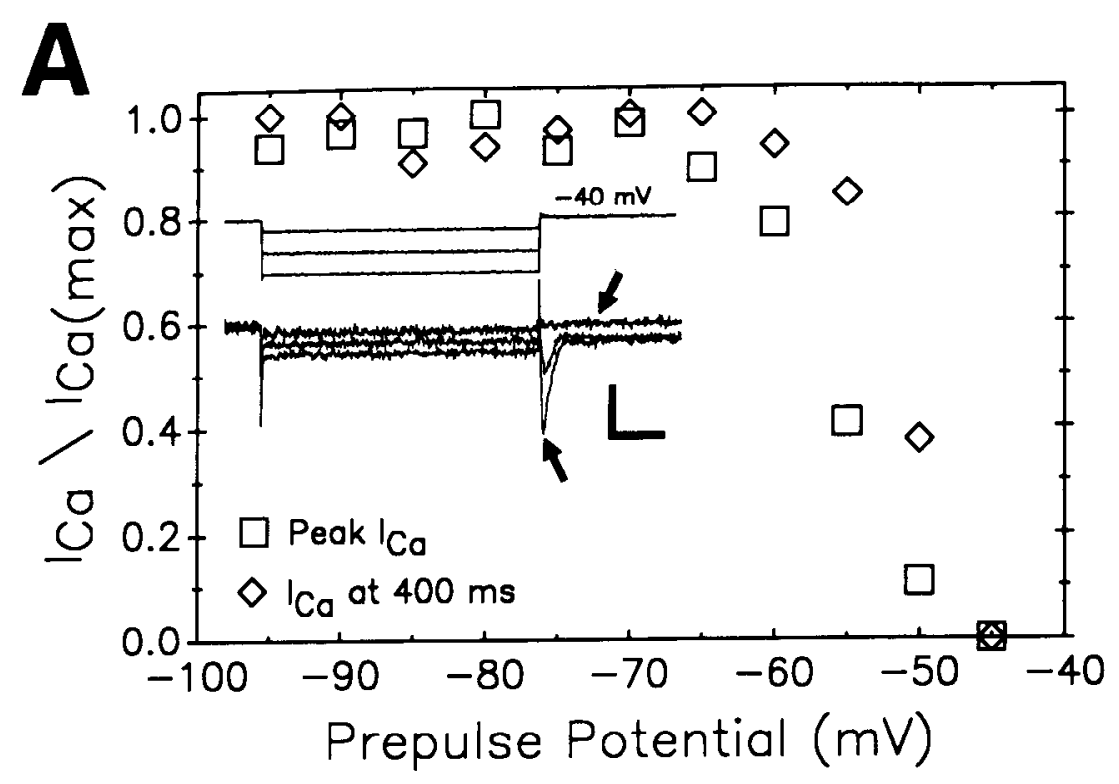

B

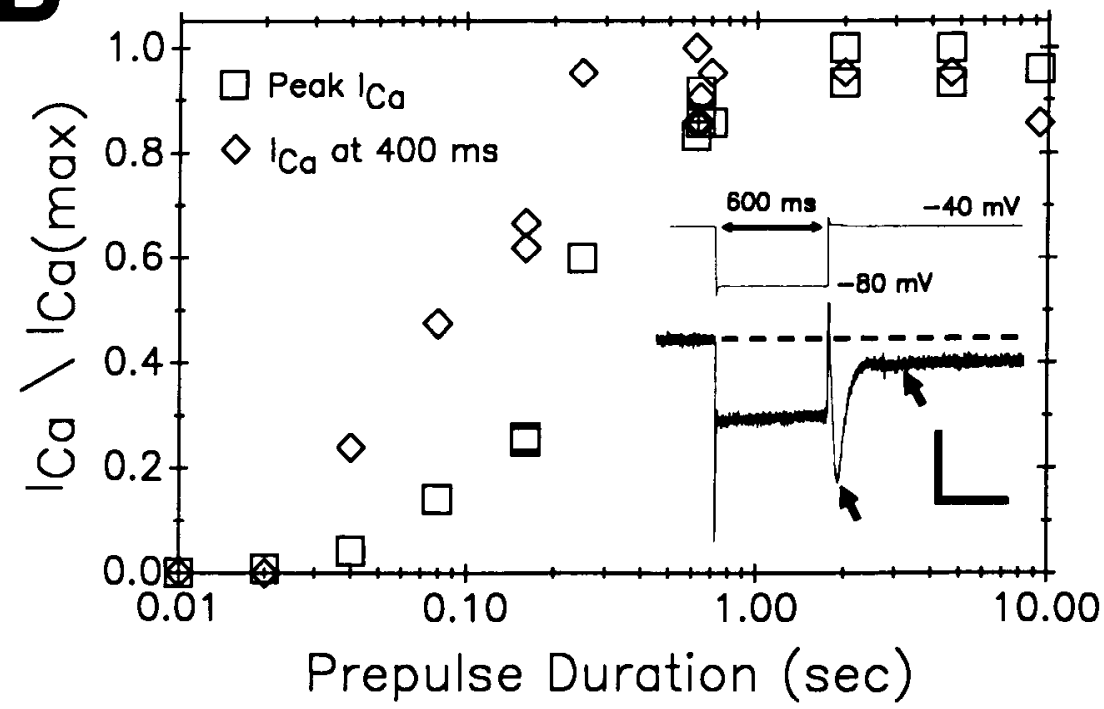

Figure 9. Steady-state inactivation of $\mathrm{Ca}^{2+}$ currents. A, Graph illustrates the peak (squares) and persistent (diamonds) inward currents (expressed as a fraction of the maximum peak or persistent current, respectively) recorded at the offset of 2-sec hyperpolarizing voltage steps versus prepulse potential. The holding potential was $-40 \mathrm{mV}$. The inset illustrates the voltage and current traces for steps to $-45 \mathrm{mV},-55 \mathrm{mV}$, and $-65 \mathrm{mV}$. Peak and persistent inward currents (marked by arrows) were measured relative to the holding current. Calibration: $25 \mathrm{mV}, 500 \mathrm{pA} ; 400$ msec. $B$, Rate of recovery from steadystate inactivation. The duration of hyperpolarizing prepulses from the holding potential of $-40 \mathrm{mV}$ to a command potential of $-80 \mathrm{mV}$ was varied systematically. The peak (squares) and persistent (diamonds) inward currents recorded at step offset are expressed as a fraction of the maximum current and plotted versus prepulse duration. The inset shows the voltage and current records for a 600 -msec prepulse. Peak and persistent inward currents (marked by arrows) were measured relative to the holding current (dashed line). Calibration: $50 \mathrm{mV}, 500 \mathrm{pA} ; 400 \mathrm{msec}$. trates data from a representative preparation $(n=7)$. Both the transient and the persistent currents begin to inactivate near $-70 \mathrm{mV}$ and are completely inactivated positive to $-50 \mathrm{mV}$. Note that half of the steady-state inactivation is removed by voltage steps to approximately $-55 \mathrm{mV}$, which corresponds to the peak hyperpolarization of the $\mathrm{HN}$ cell during bursting activity in normal physiological saline $(-55$ to $-60 \mathrm{mV})$. Similar results were obtained in 4 additional preparations in which inward currents were measured during voltage steps to a standard test potential (e.g., $-40 \mathrm{mV}$ ) while varying the holding potential.

The time course of recovery from inactivation was examined in separate experiments by varying the duration of a standard hyperpolarizing prepulse to -75 or $-80 \mathrm{mV}$ from a holding potential of $-40 \mathrm{mV}$. Figure $9 B$ shows the time course of recovery of the transient and persistent inward currents in a representative preparation $(n=7)$. Complete removal of inactivation occurred in 1-2 sec. We also found that the persistent component of inward current (defined as the current measured at $400 \mathrm{msec}$ after step offset) consistently recovered more quickly than the transient inward current. The time to half-recovery was $120 \pm 20$ ( \pm SEM) msec for the persistent inward current and $320 \pm 70 \mathrm{msec}$ for the transient inward current (based on linear regression of the steepest portions of the curves). These values are statistically different $(p<0.025 ; t=3.61$; df $=6$; paired $t$ test).

\section{Transient and persistent inward currents underlie plateau potentials in Na-free saline}

In $\mathrm{Na}$-free saline, $\mathrm{HN}$ cells can produce regenerative, $\mathrm{Ca}^{2+}$-dependent plateau potentials in response to injected currents (Arbas and Calabrese, 1987a). Similar plateau potentials were obtained in this study using TEA electrodes and $\mathrm{Na}$-free saline containing $4 \mathrm{~mm} \mathrm{Cs}^{+}$and $5 \mathrm{~mm} 4$-AP. Figure $10 \mathrm{~A}$ shows a plateau potential in an $\mathrm{HN}(\mathrm{R}, 3)$ cell (middle trace) recorded in 


\section{A CURRENT CLAMP B VOLTAGE CLAMP}
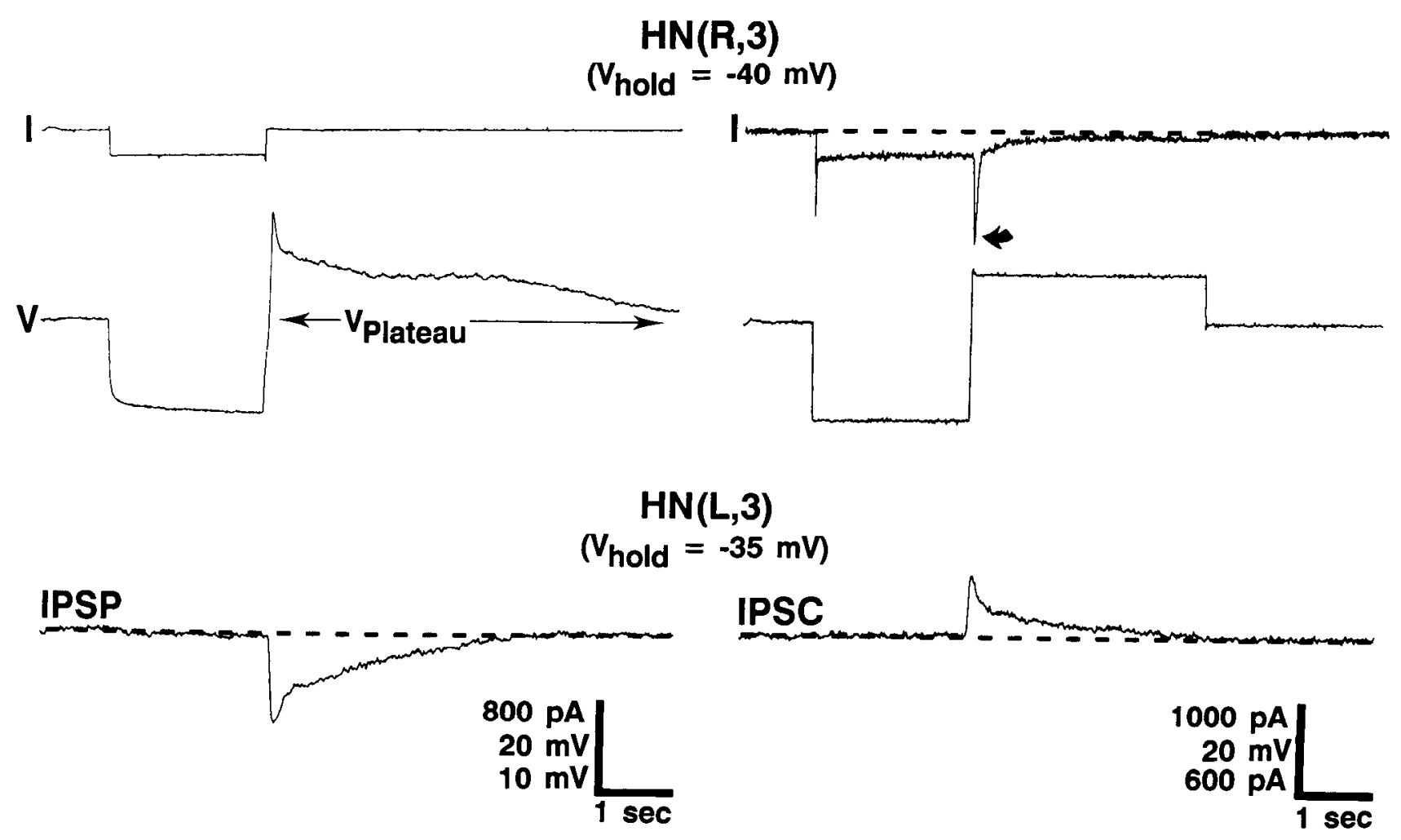

Figure 10. The peak and persistent $\mathrm{Ca}^{2+}$ currents underlie voltage-dependent plateau potentials in the $\mathrm{HN}$ cells. $A$, The top trace is a record of a hyperpolarizing current pulse delivered to an $\mathrm{HN}(\mathbf{R}, 3)$ cell in Na-free saline containing $5 \mathrm{mM} \mathrm{Ca}^{2+}$. The middle trace shows the plateau potential elicited at the offset of the current pulse. The bottom trace shows the IPSP elicited in the contralateral HN(L,3) cell in response to the plateau potential. Both HN cells were recorded in DCC mode. $B$, Same HN cells recorded in SEVC mode. The time course and amplitude of the voltage commands (middle trace) were chosen to provide an approximation of the voltage wave form observed in current clamp ( $A$, middle trace). The top trace shows the ionic currents elicited by the voltage commands. The hyperpolarizing voltage step elicits an inward current with a small outward relaxation. The currents produced by the subsequent depolarizing voltage step have been leak subtracted. Leak current was obtained from a hyperpolarizing voltage step of $-10 \mathrm{mV}$ delivered from a holding potential of $-50 \mathrm{mV}$ (not shown). Note that leak currents did not exhibit timedependent changes when obtained at holding potentials of $-50 \mathrm{mV}$ or more negative. Leak subtraction reveals transient (arrow) and persistent inward currents in response to depolarization. The bottom trace shows the postsynaptic current elicited in the contralateral HN cell in response to the presynaptic voltage step.

DCC at the offset of a hyperpolarizing current pulse (top trace) delivered from a holding potential of $-40 \mathrm{mV}$. During the current pulse, the HN cell was hyperpolarized to approximately $-60 \mathrm{mV}$. At current offset, a complex plateau potential consisting of an early depolarizing transient followed by a prolonged plateau (near $-30 \mathrm{mV}$ ) was evoked. A simultaneous recording of the $H N(L, 3)$ cell (bottom trace) revealed a similarly prolonged IPSP in response to the presynaptic plateau potential. A recording of the same HN cell in SEVC mode reveals the ionic currents underlying the plateau potential (Fig. 10B). From a holding potential of $-40 \mathrm{mV}$, the $\mathrm{HN}(\mathrm{R}, 3)$ cell was first stepped to a potential of $-60 \mathrm{mV}$, and then depolarized to $-30 \mathrm{mV}$ (to mimic the membrane potential changes observed in DCC). The depolarizing voltage step elicited the characteristic biphasic sequence of inward currents (top trace) consisting of a relatively large but transient current (arrow), followed by a smaller current that persisted for the duration of the 3-sec voltage step. Note that membrane currents shown during the depolarizing voltage step were leak subtracted (see Fig. 10 caption). The bottom trace shows the IPSC recorded in the contralateral HN cell; this cur- rent underlies the IPSP recorded in current-clamp mode. Thus, this experiment provides a qualitative illustration of the preand postsynaptic currents, which in combination with action potential currents, underlie the burst of one $\mathrm{HN}$ cell and the inhibition of the other.

\section{Discussion}

Inward $\mathrm{Ca}^{2+}$ currents underlie plateau potentials and graded synaptic transmission of $H N$ cells

Using the single-electrode voltage-clamp technique, we have identified 2 kinetically distinct components of inward current with ionic dependencies and voltage-dependent properties identical to those reported previously for plateau potentials of $\mathrm{HN}$ cells recorded in current-clamp studies (Arbas and Calabrese, 1987a). The inward currents, like plateau potentials, persist in $\mathrm{Na}$-free saline, are enhanced by elevating extracellular $\mathrm{Ca}^{2+}$, and are supported by $\mathrm{Sr}^{2+}$ and $\mathrm{Ba}^{2+}$, but not $\mathrm{Co}^{2+}$. In addition, we have shown that steady-state inactivation of both the transient and the persistent $\mathrm{Ca}^{2+}$ currents is complete positive to -50 $\mathrm{mV}$. This is in good agreement with the observation that plateau 
potentials cannot be evoked by depolarizing current pulses from holding potentials positive to about $-50 \mathrm{mV}$ (Arbas and Calabrese, 1987a). Our data showing that the activation threshold for $\mathrm{Ca}^{2+}$ currents is near $-55 \mathrm{mV}$ also explains why it is impossible to evoke plateau potentials at the offset of hyperpolarizing pulses when the holding potential is negative to $-55 \mathrm{mV}$ (Arbas and Calabrese, 1987a). Based on their similar voltage and ionic dependencies, we conclude that the $\mathrm{Ca}^{2+}$ currents recorded in voltage clamp underlie the plateau potentials observed in current-clamp studies.

In this study, we also demonstrated a strong correlation between voltage-dependent $\mathrm{Ca}^{2+}$ currents and graded synaptic transmission in HN cells. Synaptic responses are observed only following activation of inward $\mathrm{Ca}^{2+}$ currents in the presynaptic $\mathrm{HN}$ cell. In addition, the sequence of $\mathrm{Ca}^{2+}$ currents activated by depolarizing voltage steps, that is, transient inward current followed by a persistent inward current, is well correlated with the biphasic wave form of the IPSC, which consists of a peak outward current followed by a more slowly decaying component. However, we have not directly ruled out the possibility that a different population of $\mathrm{Ca}^{2+}$ channels, perhaps located in the distal dendrites of the HN cell, are in fact mediating transmitter release. Nevertheless, we believe the simplest interpretation of our results is that both the transient and the persistent components of $\mathrm{Ca}^{2+}$ current contribute directly to transmitter release.

\section{Properties of $\mathrm{Ca}^{2+}$ currents in $\mathrm{HN}$ cells and comparison to $\mathrm{Ca}^{2+}$ currents in other preparations}

Both the transient and the persistent components of $\mathrm{Ca}^{2+}$ current in $\mathrm{HN}$ cells, which begin to activate near $-60 \mathrm{mV}$, fall into the general class of low-threshold $\mathrm{Ca}^{2+}$ currents. In contrast, $\mathrm{Ca}^{2+}$ currents reported in other leech neurons have so far been of the high-threshold type, activating near - $10 \mathrm{mV}$ (Johansen et al., 1987; Stewart et al., 1989). Low-threshold $\mathrm{Ca}^{2+}$ currents have been described in other invertebrate preparations, however. These include the $\mathrm{Ca}^{2+}$ current of presynaptic terminals at the squid giant synapse, which like the persistent $\mathrm{Ca}^{2+}$ current of $\mathrm{HN}$ cells, activates near $-50 \mathrm{mV}$ and shows significant inactivation only after several seconds (Augustine et al., 1987). The transient $\mathrm{Ca}^{2+}$ current of $\mathrm{HN}$ cells shows some similarity to a low-voltage activated current described in neuron B5 of Helisoma, which is activated at about $-40 \mathrm{mV}$ and decays to 0 within 200 msec (Haydon and Man-Son-Hing, 1988). $\mathrm{Ca}^{2+}$ currents in $\mathrm{HN}$ cells also show some similarity to the $\mathrm{Ca}^{2+}$ current underlying driver potentials in lobster cardiac ganglion neurons, which begins to activate near $-40 \mathrm{mV}$ and exhibits biphasic decay (Tazaki and Cooke, 1990). Vertebrate neurons have been reported to contain up to 3 types of $\mathrm{Ca}^{2+}$ channels, labeled $\mathrm{T}$-, N-, and L-type (Nowycky et al., 1985; Fox et al., 1987a,b). There is no clear correlation between $\mathrm{HN}$ cell $\mathrm{Ca}^{2+}$ currents and any of the vertebrate channel types. However, based on activation threshold, the $\mathrm{HN} \mathrm{Ca}^{2+}$ currents resemble the T-type (lowthreshold) channels rather than $\mathrm{N}$ - or L-type (high-threshold) channels.

Both the transient and the persistent components of $\mathrm{Ca}^{2+}$ current in $\mathrm{HN}$ cells decay during prolonged depolarizing voltage steps. Our data suggest that this decay is due to inactivation of $\mathrm{Ca}^{2+}$ currents, which begins at voltages positive to about -70 $\mathrm{mV}$. It is possible, however, that an apparent decay of inward currents could result from contamination due to activation of outward currents (i.e., voltage- or $\mathrm{Ca}^{2+}$-dependent $\mathrm{K}^{+}$currents).
Although outward currents in HN cells have not been examined in detail, preliminary experiments (performed with salines in which $\mathrm{Ca}^{2+}$ channel blockers are substituted for $\mathrm{Ca}^{2+}$ ) suggest that $\mathrm{HN}$ cells possess at least 2 types. One is a transient current, similar to the molluscan A-current (Connor and Stevens, 1971), that activates at approximately $-35 \mathrm{mV}$ and then inactivates within 100-200 msec. The other is a persistent outward current, similar to the delayed rectifier of many cells, that has an activation threshold near $-30 \mathrm{mV}$ and only partially inactivates over hundreds of milliseconds. The transient current is suppressed by 4-AP, and both currents are strongly suppressed by intracellular TEA. The relatively depolarized activation thresholds of outward currents (compared to the $\mathrm{Ca}^{2+}$ current) and the use of extracellular 4-AP and intracellular TEA in our experiments suggest that the decay of inward currents is unlikely to result from distortion by voltage-dependent outward currents. Another possible source of contamination would be a Ca-activated $\mathrm{K}^{+}$current. Although the presence of a Ca-activated $\mathrm{K}^{+}$ current in HN cells cannot be ruled out, we have no clear evidence for such a current. For example, following the offset of short voltage steps (e.g., Fig. 5), the membrane current returns to the holding level, with no indication of an outward current activated by the $\mathrm{Ca}^{2+}$ influx. Another characteristic of cells with a strong $I_{\mathrm{K}(\mathrm{Ca})}$ is strong and persistent hyperpolarizing afterpotentials following $\mathrm{Ca}^{2+}$-mediated spikes or plateau potentials. In contrast, membrane potential trajectories following plateau potentials in $\mathrm{HN}$ cells are characterized by a gradual decline toward the resting potential (Fig. 10A; see also Arbas and Calabrese, 1987a). Thus, it seems unlikely that the decay of these currents, particularly the rapid decline of the transient $\mathrm{Ca}^{2+}$ current, is due to contamination by outward currents.

Inactivation of $\mathrm{Ca}^{2+}$ channels in neurons of both vertebrates (Pitler and Landfield, 1987; Akaike et al., 1988) and invertebrates (Eckert and Tillotson, 1981; Plant et al., 1983; Tazaki and Cooke, 1990) appears to be mediated, in large part, by $\mathrm{Ca}^{2+}$ influx. Our data provide circumstantial evidence that an important component of inactivation, particularly with regard to decay of the transient $\mathrm{Ca}^{2+}$ current, is also $\mathrm{Ca}^{2+}$ mediated. A comparison of inward currents elicited in $2 \mathrm{mM}$ versus $5 \mathrm{~mm}$ $\left[\mathrm{Ca}^{2+}\right]_{0}$ shows that the rate of decay of the transient $\mathrm{Ca}^{2+}$ current is better correlated with peak current amplitude than with membrane potential. For example, the rate of decay of the transient calcium current elicited by the voltage step to $-35 \mathrm{mV}$ in $2 \mathrm{~mm}$ $\mathrm{Ca}^{2+}$ (Fig. 2A) is slower than that observed for the comparable voltage step in $5 \mathrm{mM} \mathrm{Ca}^{2+}$, but is very similar to the rate of decay of the transient current elicited by the step to $-42.5 \mathrm{mV}$ in $5 \mathrm{mM} \mathrm{Ca}^{2+}$, which has a similar peak amplitude (Fig. $3 A$ ). The hypothesis that inactivation is mediated by $\mathrm{Ca}^{2+}$ influx is also supportcd by the decreascd rate of inactivation of the transient current that occurs when $\mathrm{Ba}^{2+}$ is used as the charge carrier (e.g., Fig. 8C). In fact, it was often difficult to distinguish the 2 components of inward current in the presence of $\mathrm{Ba}^{2+}$. Several studies have suggested that $\mathrm{Ba}^{2+}$ ions are much less effective than $\mathrm{Ca}^{2+}$ for mediating inactivation of calcium channels (Eckert and Tillotson, 1981; Kalman et al., 1988).

Are the transient and persistent components of calcium current generated by 1 or 2 classes of Ca channels?

Calcium currents evoked in HN cells consistently exhibited a biphasic relaxation during prolonged voltage steps, and we have referred to these 2 kinetically distinct components as the transient and persistent $\mathrm{Ca}^{2+}$ currents. It is possible that the $2 \mathrm{com}$ - 
ponents of inward current are produced by 2 different classes of $\mathrm{Ca}^{2+}$ channels, one that inactivates relatively quickly and another that inactivates only very slowly. However, it is also possible that only 1 class of channels is present in HN cells and that other mechanisms underlie the biphasic wave form of the observed currents.

If we suppose that $\mathrm{HN}$ cells possess only 1 class of $\mathrm{Ca}^{2+}$ channels, then what other mechanisms might explain the biphasic form of the inward currents that is observed? One explanation would be distortion of inward currents due to contamination by $\mathrm{Ca}^{2+}$-activated $\mathrm{K}^{+}$current. As discussed above, our data do not rule out this possibility. Another possible explanation is that the biphasic wave form of $\mathrm{Ca}^{2+}$ currents arises as a property of $\mathrm{Ca}^{2+}$-mediated inactivation, a mechanism that has been proposed to explain the biphasic decay of $\mathrm{Ca}^{2+}$ current in some Aplysia neurons (Chad et al., 1984; Eckert and Chad, 1984). According to this model, the rapid rise of $\left[\mathrm{Ca}^{2+}\right]_{i}$ at the inner surface of the plasma membrane following the initial surge of $\mathrm{Ca}^{2+}$ influx underlies a rapid component of inactivation. However, due to internal buffering of free $\mathrm{Ca}^{2+},\left[\mathrm{Ca}^{2+}\right]_{i}$ never rises to a level sufficient to inactivate all the $\mathrm{Ca}^{2+}$ channels. Thus, a persistent component of $\mathrm{Ca}^{2+}$ current, whose magnitude depends on the steady-state $\left[\mathrm{Ca}^{2+}\right]_{i}$, is observed. A similar mechanism could contribute to the biphasic wave form of calcium currents in HN cells. Our observation that the transient component of $\mathrm{Ca}^{2+}$ current appeared to be more sensitive than the persistent component to block by cobalt saline (Fig. 7) is also consistent with the data of Chad et al. (1984) showing a preferential depression of peak $\mathrm{Ca}^{2+}$ current relative to persistent $\mathrm{Ca}^{2+}$ current during partial block by $\mathrm{Cd}^{2+}$ ions.

\section{Graded synaptic transmission between reciprocally inhibitory} $H N$ cells

We have shown that transmitter release and postsynaptic responses of reciprocally inhibitory $\mathrm{HN}$ cells in $\mathrm{G} 3$ and $\mathrm{G} 4$ persist in the complete absence of $\mathrm{Na}^{+}$-mediated action potentials. Circumstantial evidence suggests that graded synaptic transmission may contribute to inhibition of the contralateral $\mathrm{HN}$ cell in normal leech saline. Previous studies have noted that subthreshold depolarization of $\mathrm{HN}$ cells can inhibit postsynaptic heart motor neurons, an effect attributed to a nonspiking component of synaptic transmission (Thompson and Stent, 1976b; Nicholls and Wallace, 1978a). Arbas and Calabrese (1987b) observed similar effects between HN cells at the offset of hyperpolarizing current pulses. The data reported in this study are also consistent with a role for graded synaptic transmission during normal rhythmic activity. During a burst, action potentials in an $\mathrm{HN}$ cell ride atop a slow oscillation that peaks at approximately $-35 \mathrm{mV}$. When inhibited, the HN cell is hyperpolarized to between -50 and $-60 \mathrm{mV}$. Thus, the subthreshold membrane potential oscillations of the HN cell overlap almost exactly with the synaptic transfer function obtained in this study, which shows that transmitter release begins at -45 to $-47 \mathrm{mV}$ and peaks near $-35 \mathrm{mV}$. This suggests that both graded and spike-mediated synaptic effects will contribute to the inhibition of the contralateral $\mathrm{HN}$ cell during normal rhythmic activity. Combined actions of spike-mediated and graded synaptic transmission similar to those proposed here have been clearly demonstrated between neurons in the lobster stomatogastric ganglion (Graubard et al., 1983).

The synaptic transfer function of the HN-to-HN synapse is rather steep. In $2 \mathrm{mM} \mathrm{Ca}^{2+}$, an $8-11 \mathrm{mV}$ presynaptic depolariza- tion produced a 10 -fold change in the peak IPSP. This relationship corresponds fairly closely to that found at other synapses, including the squid giant synapse (Katz and Miledi, 1967), a tonic sensorimotor synapse in the crab (Blight and Llinas, 1980), the photoreceptor to I-cell synapse in the barnacle (Hayashi et al., 1985), and the Retzius to P-cell synapse of leech neurons in cell culture (Dietzel et al., 1986). However, this relationship is steeper than that reported for graded transmission between spiking neurons in the lobster stomatogastric system (Graubard, 1978; Graubard et al., 1989) and the Müller's cell's synapse in the lamprey (Martin and Ringham, 1975). Hayashi et al. (1985) have suggested that a steep input-output relation may be favored at relay synapses, where it is important to insure that the postsynaptic cell is driven by presynaptic changes. In the HN cell synapse, it is also important that the postsynaptic cell responds strongly to presynaptic depolarization, because burst termination is a critical transition in the oscillation (scc below).

\section{Mechanisms for alternate bursting of reciprocally inhibitory $H N$ cells}

The reciprocally inhibitory $\mathrm{HN}(3)$ and $\mathrm{HN}(4)$ cell pairs each form competent oscillators. When one of the HN cells is inhibited by a burst of action potentials in its contralateral partner, it slowly depolarizes toward its own burst threshold and a resulting inhibition of the previously active cell. It is this transition from inhibition to burst formation that is the critical timing event of the oscillation (Peterson, 1983). One important mechanism for recovery from inhibition is activation of voltage-gated ionic currents. Previous studies showed that one of these currents, $I_{h}$, is activated at membrane potentials negative to -45 $\mathrm{mV}$ and causes the HN cell to depolarize its response to hyperpolarizing inputs (Angstadt and Calabrese, 1989). Moreover, pharmacological block of $I_{h}$ severely disrupts the normal bursting activity of reciprocally inhibitory $\mathrm{HN}$ cell pairs. In this paper, we have identified voltage-dependent $\mathrm{Ca}^{2+}$ currents that underlie a plateau potential that supports burst formation following prior hyperpolarization. Our data suggest that hyperpolarization is required in order to remove inactivation of the $\mathrm{Ca}^{21}$ currents and thereby allow activation during subsequent depolarization (driven by $I_{h}$ ). The discovery of 2 kinetically distinct components of $\mathrm{Ca}^{2+}$ current raises the possibility that each component may play a qualitatively different functional role. For example, the large transient $\mathrm{Ca}^{2+}$ current could be important for ensuring a surge of $\mathrm{Ca}^{2+}$ influx (and consequent transmitter release) and thus a vigorous inhibition of the contralateral $\mathrm{HN}$ cell (i.e., to guarantee burst termination). The persistent inward current, on the other hand, may provide for longer-lasting inhibition ( $1-2 \mathrm{sec})$ that, coupled with spike-mediated inhibition, prevents recovery of the contralateral HN cell toward its next burst from occurring too quickly.

The combined actions of $I_{h}$ and $I_{\mathrm{Ca}}$ could account for the escape from inhibition and subsequent burst generation of the HN cells. In theory, however, there are other mechanisms that could contribute to the recovery of an inhibited HN cell. For example, it is possible that, in the absence of a time-dependent decline in the strength of synaptic inhibition, the depolarizing effects of $I_{h}$ would not be sufficient to allow the inhibited HN cell to recover to burst threshold. Peterson (1983) found no evidence for a decreased efficacy of spike-mediated transmission during a burst. In contrast, the data presented in this study suggest that inhibition produced by graded synaptic transmis- 
sion would be expected to wane significantly during the prolonged depolarization associated with a burst $(\sim 5 \mathrm{sec})$. The relative contribution of spike-mediated and graded synaptic transmission to the overall inhibition of the contralateral $\mathrm{HN}$ cell is being investigated by incorporating data on ionic currents and synaptic transmission into a mathematical model of reciprocally inhibitory $\mathrm{HN}$ cells (De Schutter et al., 1989).

\section{References}

Akaike N, Tsuda Y, Oyama Y (1988) Separation of current- and voltage-dependent inactivation of calcium current in frog sensory neuron. Neurosci Lett 84:46-50.

Angstadi JD, Calabrese RL (1989) A hyperpolarization-activated inward current in heart interneurons of the medicinal leech. J Neurosci 9:2846-2857.

Arbas EA, Calabrese RL (1987a) Ionic conductances underlying the activity of interneurons that control heartbeat in the medicinal leech. J Neurosci 7:3945-3952.

Arbas EA, Calabrese RL (1987b) Slow oscillations of membrane potential in interneurons that control heartbeat in the medicinal leech. J Neurosci 7:3953-3960.

Augustine GJ, Charlton MP, Smith SJ (1987) Calcium action in synaptic transmitter release. Annu Rev Neurosci 10:633-693.

Blight AR, Llinas R (1980) The non-impulsive stretch-receptor complex of the crab: a study of depolarization-release coupling at a tonic sensorimotor synapse. Philos Trans Soc Lond [Biol] 290:219-276.

Calabrese RL (1977) The neural control of alternate heartbeat coordination states in the leech, Hirudo medicinalis. J Comp Physiol 122: 111-143.

Calabrese RL, Angstadt JD, Arbas EA (1989) A neural oscillator based on reciprocal inhibition. In: Perspectives in neural systems and behavior (Carew TJ, Kelly D, eds), pp 33-50. New York: Liss.

Chad J, Eckert R, Ewald D (1984) Kinetics of calcium-dependent inactivation of calcium current in voltage-clamped neurones of $A p l y$ sia californica. J Physiol (I ond) 347:279-300.

Connor JA, Stevens CF (1971) Voltage clamp studies of a transient outward membrane current in gastropod neural somata. J Physiol (Lond) 213:21-30.

De Schutter E, Simon TW, Angstadt JD, Calabrese RL (1989) Computer simulation of oscillation in mutually inhibitory heart interneurons in leech. Soc Neurosci Abstr 15:1049.

Dietzel ID, Drapeau P, Nicholls JG (1986) Voltage dependence of 5 -hydroxytryptamine release at a synapse between identified leech neurones in culture. J Physiol (Lond) 372:191-205.

Eckert R, Chad JE (1984) Inactivation of Ca channels. Prog Biophys Mol Biol 44:215-267.

Eckert R, Tillotson DL (1981) Calcium-mediated inactivation of the calcium conductance in caesium-loaded giant neurones of Aplysia californica. J Physiol (I ond) 314:265-280.

Fox AP, Nowycky MC, Tsien RW (1987a) Kinetic and pharmacological properties distinguishing three types of calcium currents in chick sensory neurones. J Physiol (Lond) 394:149-172.

Fox AP, Nowycky MC, Tsien RW (1987b) Single-channel recordings of three types of calcium channels in chick sensory neurones. J. Physiol (Lond) 394:173-200.

Graubard K (1978) Synaptic transmission without action potentials: input-output properties of a nonspiking presynaptic neuron. J Neurophysiol 41:1014-1025.

Graubard K, Raper JA, Hartline DK (1983) Graded synaptic transmission between identified spiking neurons. J Neurophysiol 50:508521.
Graubard K, Raper JA, Hartline DK (1989) Quantitative analysis of non-spiking synaptic transmission between spiking stomatogastric neurons. Soc Neurosci Abstr 15:1047.

Hayashi JH, Moore JW, Stuart AE (1985) Adaptation in the inputoutput relation of the synapse made by the barnacle's photoreceptor. J Physiol (Lond) 368:179-195.

Haydon PG, Man-Son-Hing H (1988) Low- and high-voltage-activated calcium currents: their relationship to the site of neurotransmitter release in an identified neuron of Helisoma. Neuron 1:919927.

Johansen J, Yang J, Kleinhaus AL (1987) Voltage-clamp analysis of the ionic conductances in a leech neuron with a purely calcium-dependent action potential. J Neurophysiol 58:1468-1484.

Kalman D, O'Lague PH, Erxleben C, Armstrong DL (1988) Calciumdependent inactivation of the dihydropyridine-sensitive calcium channels in GH3 cells. J Gen Physiol 92:531-548.

Katz B, Miledi R (1967) A study of synaptic transmission in the absence of nerve impulses. J Physiol (Lond) 192:407-436.

Kuhlman JR, Li C, Calabrese RL (1985) FMRF-amide-like substances in the leech: II. Bioactivity on the heartbeat system. J Neurosci 5: 2310-2317.

Martin AR, Ringham GL (1975) Synaptic transfer at a vertebrate central nervous system synapse. J Physiol (Lond) 251:409-426.

Nelson MT (1986) Interactions of divalent cations with single calcium channels from rat brain synaptosomes. J Gen Physiol 87:201-222.

Nicholls JG, Baylor DA (1968) Specific modalities and receptive fields of sensory neurons in the CNS of the leech. J Neurophysiol 31:740 756.

Nicholls JG, Wallace BG (1978a) Modulation of transmission at an inhibitory synapse in the central nervous system of the leech. J Physiol (Lond) 281:157-170.

Nicholls JG, Wallace BG (1978b) Quantal analysis of transmitter release at an inhibitory synapse in the central nervous system of the leech. J Physiol (Lond) 281:171-185.

Nowycky MC, Fox AP, Tsien RW (1985) Three types of neuronal calcium channel with different calcium agonist sensitivity. Nature 316:440-443.

Peterson EL (1983) Generation and coordination of heartbeat timing oscillation in the medicinal leech. I. Oscillation in isolated ganglia. J Neurophysiol 49:611-626.

Peterson EL, Calabrese RL (1982) Dynamic analysis of a rhythmic neural circuit in the leech Hirudo medicinalis. J Neurophysiol 47: 256-271

Pitler TA, Landfield PW (1987) Probable $\mathrm{Ca}^{2+}$-mediated inactivation of $\mathrm{Ca}^{2+}$ currents in mammalian brain neurons. Brain Res 410:147153.

Plant TD, Standen NB, Ward TA (1983) The effects of injection of calcium ions and calcium chelators on calcium channel inactivation in Helix neurones. J Physiol (Lond) 334:189-212.

Stewart RR, Nicholls JG, Adams WB (1989) $\mathrm{Na}^{+}, \mathrm{K}^{+}$, and $\mathrm{Ca}^{2+}$ currents in identified leech neurones in culture. J Exp Biol 141:1-20.

Tazaki K, Cooke IM (1990) Characterization of Ca current underlying burst formation in lobster cardiac ganglion motorneurons. J Neurophysiol 63:370-384.

Thompson WJ, Stent GS (1976a) Neuronal control of heartbeat in the medicinal leech. II. Intersegmental coordination of heart motor neuron activity by heart interneurons. J Comp Physiol 111:281-307.

Thompson WJ, Stent GS (1976b) Neuronal control of heartbeat in the medicinal leech. III. Synaptic relations of the heart interneurons. J Comp Physiol 111:309-333.

Tolbert LP, Calabrese RL (1985) Anatomical analysis of contacts between identified neurons that control heartbeat in the leech Hirudo medicinalis. Cell Tissue Res 242:257-267. 